
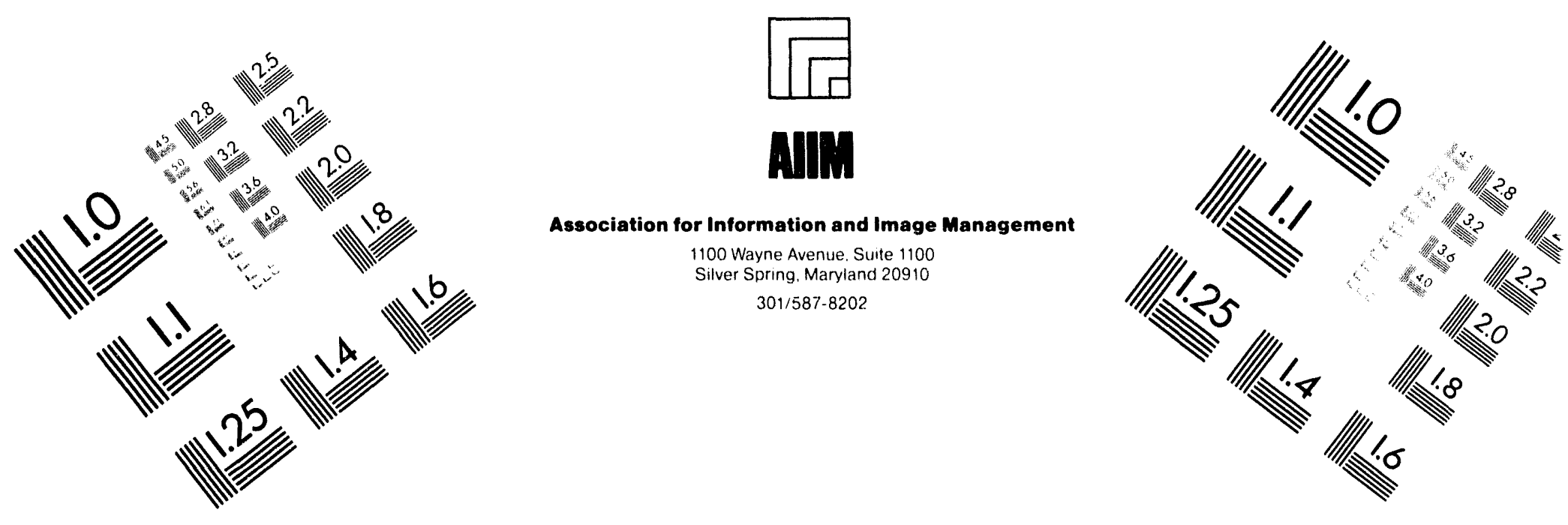

\title{
Centimeter
}

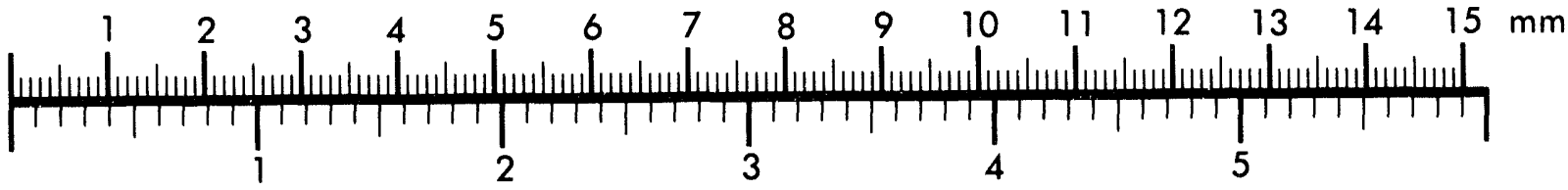
Inches
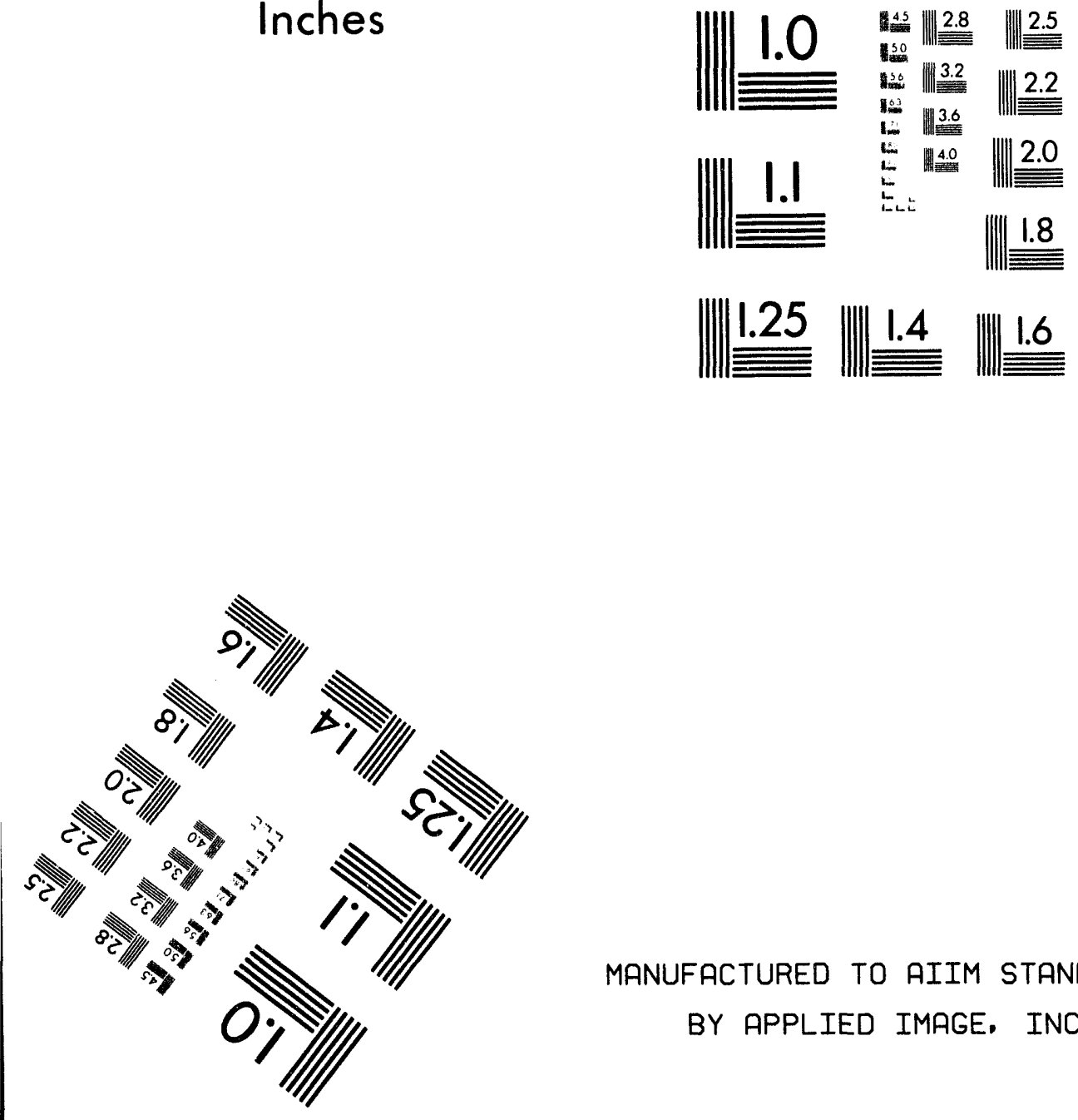

MANUFACTURED TO AIIM STANDARDS

BY APPLIED IMAGE, INC.

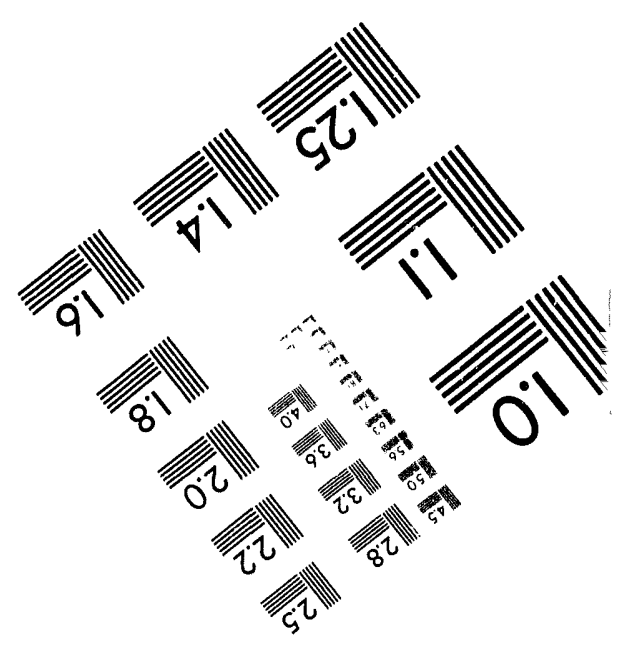



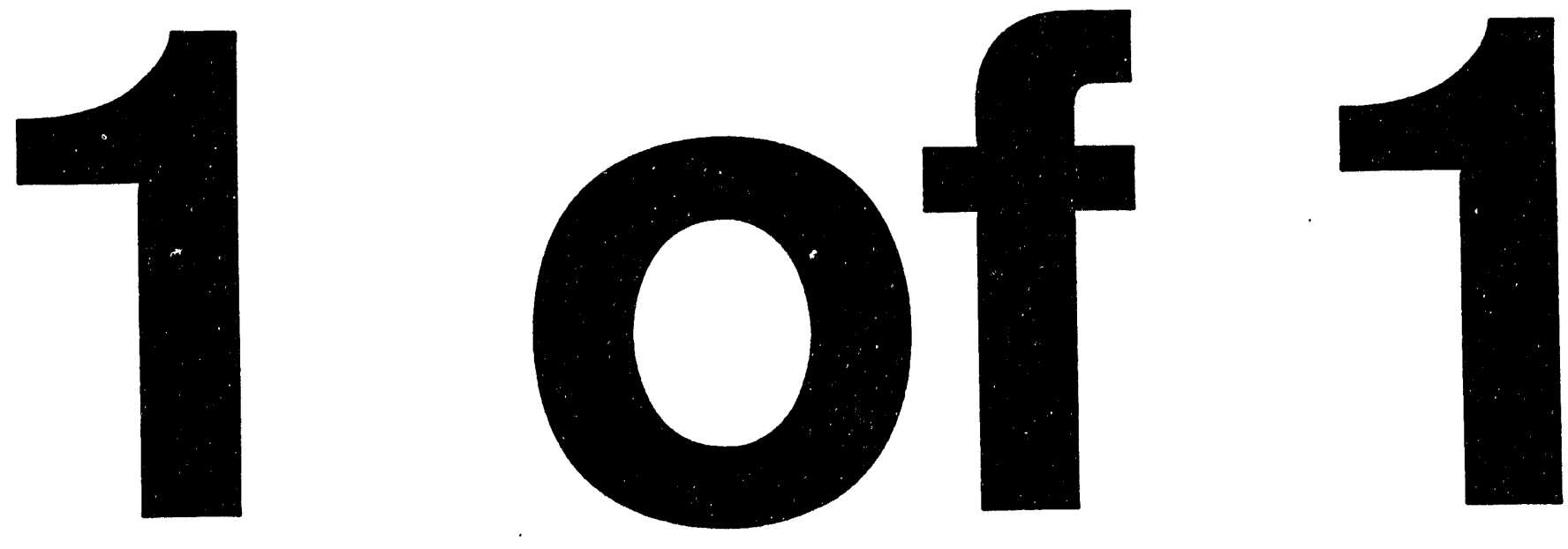


\section{AN AERIAL RADIOLOGICAL SURVEY OF THE SOUTHWEST DRAINAGE BASIN AREA OF THE SAVANNAH RIVER SITE}

AIKEN, SOUTH CAROLINA 


\section{DISCLAIMER}

This report was prepared as an account of work sponsored by an agency of the United States Government. Neither the United States Government nor any agency thereof, nor any of their employees, makes any warranty, express or implied, or assumes any legal liability or responsibility for the accuracy, completeness, or usefulness of any information, apparatus, product, or process disclosed, or represents that its use would not infringe privately owned rights. Reference herein to any specific commercial product, process, or service by trade name, trademark, manufacturer, or otherwise, does not necessarily constitute or imply its endorsement, recommendation, or favoring by the United States Government or any agency thereof. The views and opinions of authors expressed herein do not necessarily state or reflect those of the United States Government or any agency thereof.

This report has been reproduced directly from the best available copy.

Available to DOE and DOE contractors from the Office of Scientific and Technicá Information, P.O. Box 62, Oak Ridge, Tennessee 37831 ; prices available from (615) 576-8401.

Available to the public from the National Technical Information Service, U.S. Department of Commerce, 5285 Port Royal, Springfield, Virginia 22161. 


\title{
AN AERIAL RADIOLOGICAL SURVEY OF THE SOUTHWEST DRAINAGE BASINAREA OF SAVANNAH RIVER SITE
}

\author{
AIKEN, SOUTH CAROLINA
}

DATE OF SURVEY: AUGUST 1988

E. L. Feimster

Project Scientist

\section{REVIEWED BY}

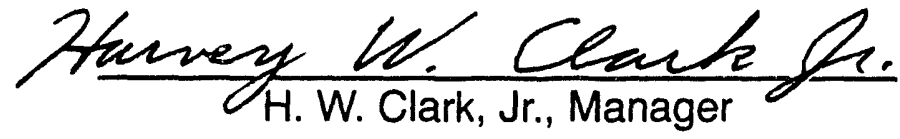

Radiation Science Section

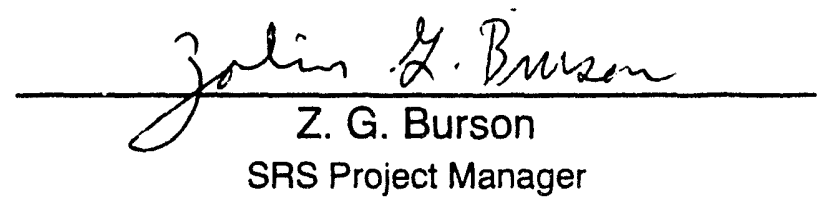

SRS Project Manager

This I cument is UNCLASSIFIED

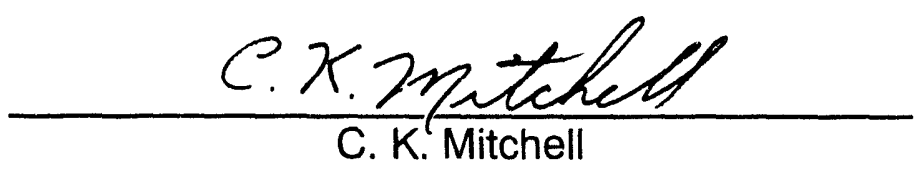

Classification Officer

This work was performed by EG\&G/EM under Contract Number DE-AC08-93NV11265 with joint funding provided by the United States Department of Energy and Westinghouse Savannah River Company, Inc., operators of the Savannah River Site and Savannah River Technology Center at the time of the survey. 


\begin{abstract}
An aerial radiological survey was conducted over a 106-square-mile area of the Savannah River Site (SRS), formerly the Savannah River Plant. The survey was conducted from August 24 through September 8, 1988, to collect baseline radiological data over the area. Both natu$\mathrm{ral}$ and man-made gamma emitting radionuclides were detected in the area. The detected man-made sources were confined to creeks, branches, and SRS facilities in the surveyed area and were a result of SRS operations. Naturally-occurring radiation levels were consistent with those levels detected in adjacent areas during previous surveys. The annual dose levels were within the range of levels found throughout the United States.
\end{abstract}




\section{CONTENTS}

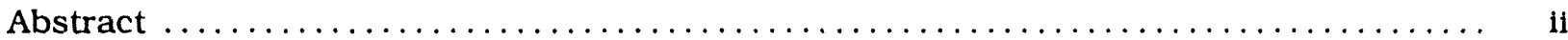

\section{Sections}

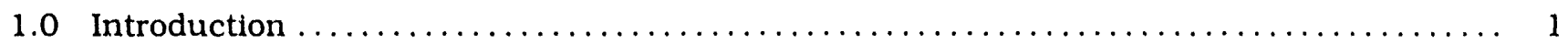

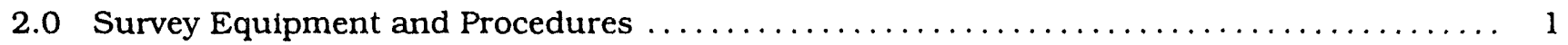

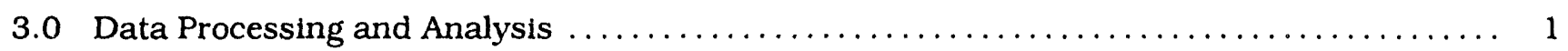

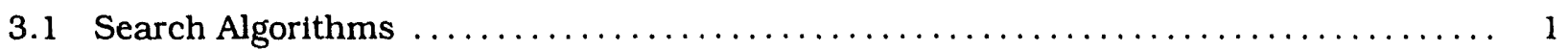

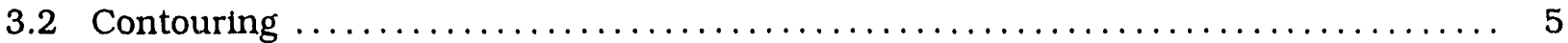

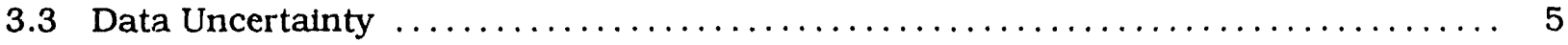

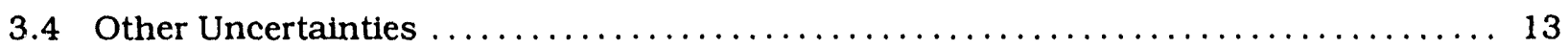

3.5 Spatial Resolution of the Detector System $\ldots \ldots \ldots \ldots \ldots \ldots \ldots \ldots \ldots \ldots \ldots \ldots$

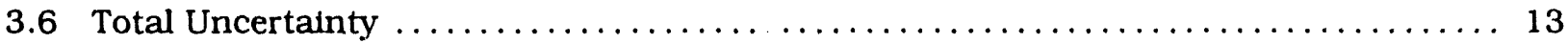

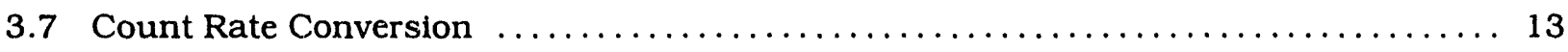

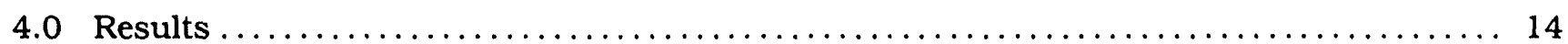

\section{Figures}

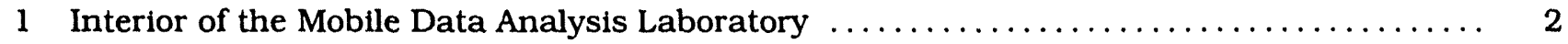

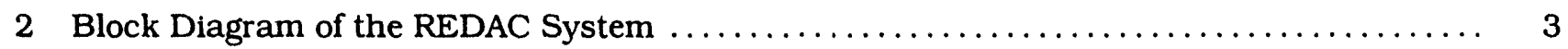

3 Total Terrestrial Gamma Count Rate Contour Map $\ldots \ldots \ldots \ldots \ldots \ldots \ldots \ldots \ldots \ldots \ldots$

4 Natural Terrestrial Exposure Contour Map $\ldots \ldots \ldots \ldots \ldots \ldots \ldots \ldots \ldots \ldots \ldots \ldots$

5 Man-Made and Excess Natural ${ }^{214} \mathrm{Bi}$ Activity Contour Map $\ldots \ldots \ldots \ldots \ldots \ldots \ldots \ldots$

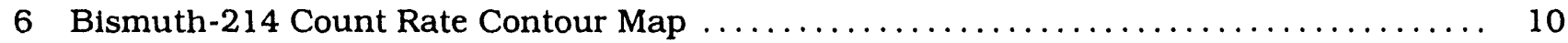

7 Cobalt-60 Exposure Rate Contour Map $\ldots \ldots \ldots \ldots \ldots \ldots \ldots \ldots \ldots \ldots \ldots \ldots \ldots \ldots$

8 Cesium-137 Exposure Rate Contour Map $\ldots \ldots \ldots \ldots \ldots \ldots \ldots \ldots \ldots \ldots \ldots \ldots \ldots$

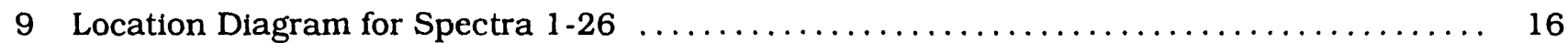

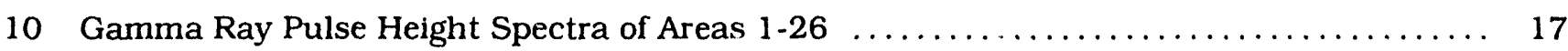

B-1 MBB BO-105 Helicopter with Detector Pods $\ldots \ldots \ldots \ldots \ldots \ldots \ldots \ldots \ldots \ldots \ldots \ldots \ldots$

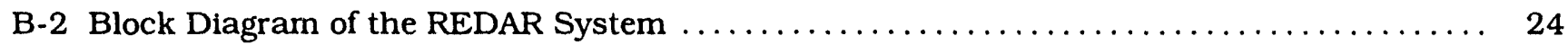




\section{Tables}

1 Count Rate Levels for Isoradiation Contours of Sources Detected at the SRS Site ....... 5

2 Contour Map Minimum Count Rates or Exposure Rates $\ldots \ldots \ldots \ldots \ldots \ldots \ldots \ldots \ldots$

3 Distributicn of Sources in the Southwest Area $\ldots \ldots \ldots \ldots \ldots \ldots \ldots \ldots \ldots \ldots \ldots \ldots, 14$

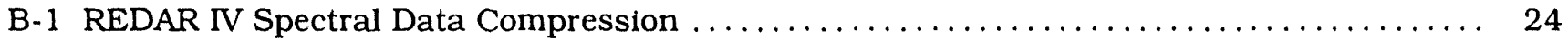

\section{Appendices}

A Survey Parameters $\ldots \ldots \ldots \ldots \ldots \ldots \ldots \ldots \ldots \ldots \ldots \ldots \ldots \ldots \ldots \ldots \ldots \ldots \ldots \ldots \ldots \ldots \ldots, 22$

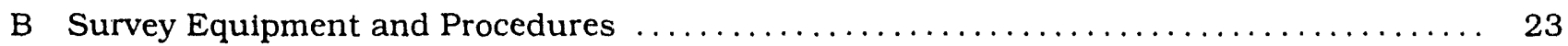

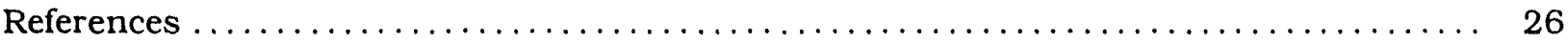




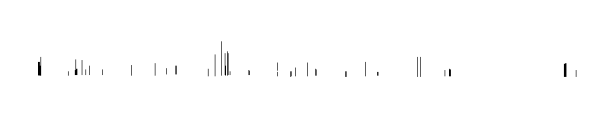

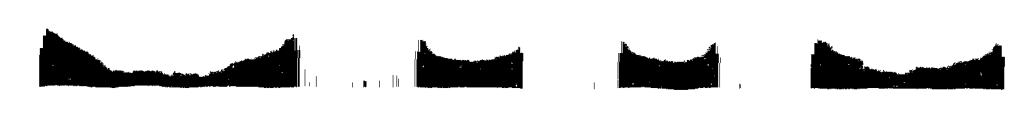

\subsection{INTRODUCTION}

An aerial radiological survey was performed over a $106-\mathrm{mi}^{2}$ portion of the Savannah River Site (SRS), formerly the Savannah River Plant, from August 24 through September 8, 1988. The survey was conducted by EG\&G Energy Measurements, Inc., (EG\&G/EM) for the Department of Energy and 'Vestinghouse Savannah River Company. Radiological surveys of this type have been performed over SRS since 1974 and comprise a portion of the Comprehensive Integrated Remote Sensing (CIRS) program. ${ }^{1-13}$ These surveys provide a database for study of transport of man-made gamma emitting radionuclides through the environment encompassing the SRS and surrounding area.

\subsection{SURVEY EQUIPMENT AND PROCEDURES}

The aerial radiological measurements were made with a thallium-activated sodium iodide, $\mathrm{NaI}(\mathrm{Tl})$, detector array and a data acquisition system mounted in a Messerschmitt-BolkowBlohm (MBB) BO-105 helicopter (Figure B-1, Appendix B). A total of 215 survey lines were flown in a northwest-southeast direction constituting 2,107 line miles. All flight lines and associated flights required approximately 45 hours of flight time. All survey flights were flown at an altitude of $200 \mathrm{ft}(61 \mathrm{~m})$ along flight paths spaced $250 \mathrm{ft}(76 \mathrm{~m})$ apart. The helicopter was flown at a speed of 70 knots $(36 \mathrm{~m} / \mathrm{s})$. Gamma radiation data detected with sodium lodide detectors, position data from an ultrahigh frequency ranging system (URS), meteorological data, and other data collection parameters were recorded on magnetic tape each second of flight using the Radiation Environmental Data Acquisition and Recorder Model IV (REDAR IV). Survey systems and parameters are described in detail in Appendices A and B.

\subsection{DATA PROCESSING AND ANALYSIS}

Processing and analysis of data recorded on magnetic tapes each flight were begun in the field utilizing the Radiation and Environmental Data Analyzer and Computer (REDAC) system, which consisted of a computer analysis laboratory mounted in a mobile van. During survey operations, the van and aircraft were based at Bush Field in Augusta, Georgia. The interior of the van is shown in Figure 1, and a block diagram of the processing system is shown in Figure 2. The REDAC system consisted primarily of an MV 7800 XP computer and peripherals. An extensive inventory of software routines was available for the preliminary data analysis, accomplished in the field, and the final analysis, accomplished after the completion of all field operations, in Las Vegas, Nevada. Some details of the analysis methodology are discussed in this report. A complete description of the data analysis software and procedures used to obtain the results may be found in a previous report. ${ }^{1}$

\subsection{Search Algorithms}

Algorithms were generated to extract the count rate due to gamma rays emitted by the following sources: 


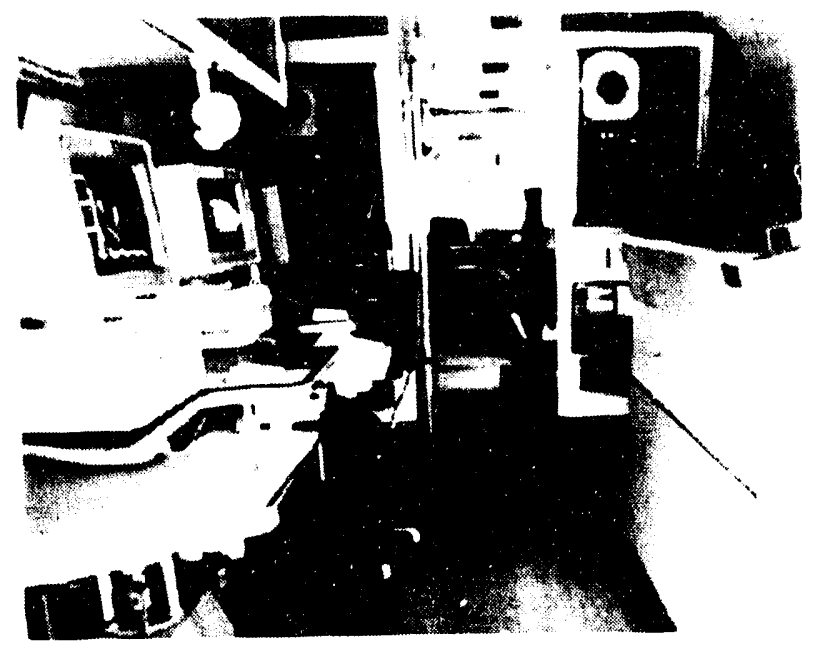

FIGURE 1. INTERIOR OF THE MOBILE DATA ANALYSIS LABORATORY

A. Total terrestrial and cosmic radionuclides (gross count)

$$
G C_{\text {terrestrial }}=\sum_{E=38 \mathrm{keV}}^{3026 \mathrm{keV}} C R(E)_{\text {total }}-\sum_{E=38 \mathrm{keV}}^{3026 \mathrm{keV}} C R(E)_{\text {nonterrestrial }}
$$

where:

$$
\begin{aligned}
G C_{\text {terrestrial }} & =\text { gross count rate } \\
C R(E)_{\text {total }} & =\text { total count rate on a survey lin€ }
\end{aligned}
$$

$C R(E)_{\text {nonterrestrial }}=$ total count rate over water

B. Estimated natural terrestrial radionuclides

$$
T C=(K+1) \cdot \sum_{E=1394 \mathrm{keV}}^{3026 \mathrm{keV}} C R(E)_{\text {total }}-\sum_{E=38 \mathrm{keV}}^{3026 \mathrm{keV}} C R(E)_{\text {nonterrestrial }}
$$

where:

$T C=$ terrestrial count rate

$K=$ ratio of the total count rate spectral sum below $1,394 \mathrm{keV}$ to the sum above 1,394 $\mathrm{keV}$. (The spectrum is measured over an area devoid of man-made sources.)

C. Total man-made radionuclides

$$
M M G C=\sum_{E=38 \mathrm{keV}}^{1394 \mathrm{keV}} C R(E)-K \sum_{E=1394 \mathrm{keV}}^{3026 \mathrm{keV}} C R(E)
$$




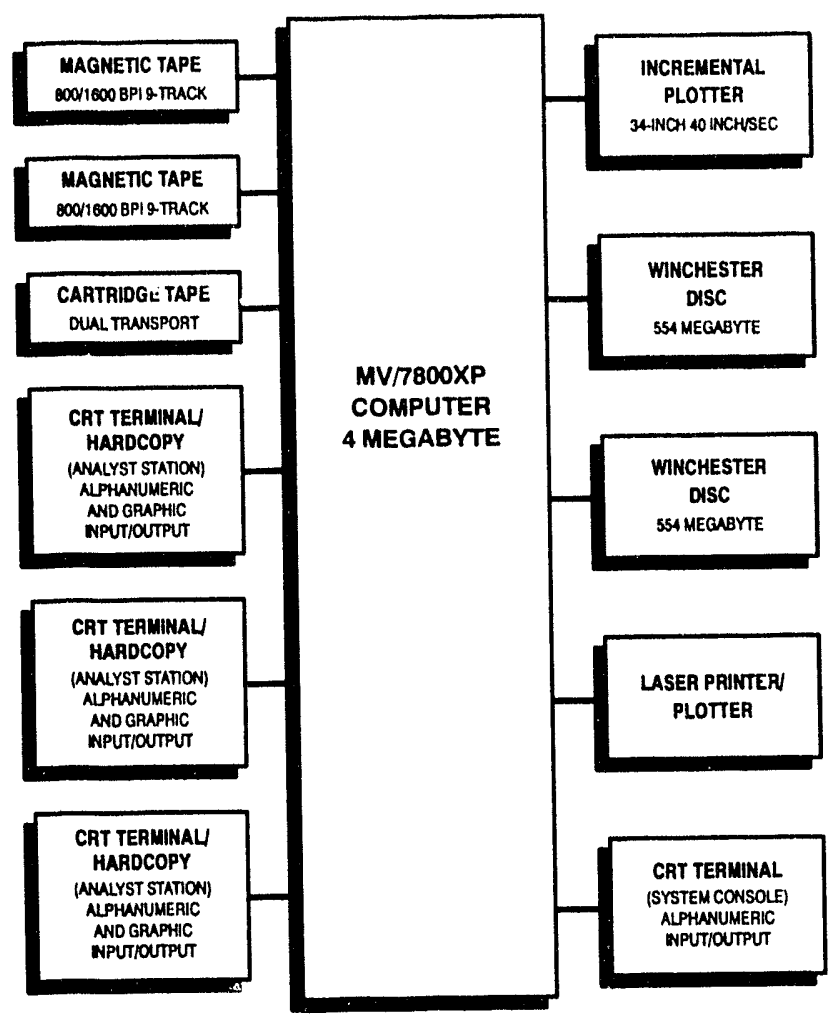

FIGURE 2. BLOCK DIAGRAM OF THE REDAC SYSTEM

where:

MMGC = man-made gross count rate

D. Bismuth-214

$$
B i=\sum_{E=1574 \mathrm{keV}}^{1946 \mathrm{keV}} C R_{E}-K_{B i} \sum_{E=2342 \mathrm{keV}}^{2882 \mathrm{keV}} C R_{E}
$$

where:

$B i=$ bismuth-214 $\left({ }^{214} \mathrm{Bi}\right)$ count rate from the $1,760 \mathrm{keV}$ photopeak

E. Cobalt -60

$$
C o=\sum_{E=1094 \mathrm{keV}}^{1394 \mathrm{keV}} C R(E)-K_{C o} \sum_{\mathrm{E}=1394 \mathrm{keV}}^{3026 \mathrm{keV}} C R(E)
$$


where:

$\mathrm{Co}=$ cobalt $-60\left({ }^{60} \mathrm{Co}\right)$ count rate in the $1,173 \mathrm{keV}$ and the $1,333 \mathrm{keV}$ photopeaks

F. Cesium-137

$$
C S=\sum_{E=590 \mathrm{keV}}^{722 \mathrm{keV}} C R(E)-K_{C s}\left[\sum_{E=518 \mathrm{keV}}^{590 \mathrm{keV}} C R(E)+\sum_{E=722 \mathrm{keV}}^{794 \mathrm{keV}} C R(E)\right]
$$

where:

$C s=$ cesium $-137\left({ }^{137} \mathrm{Cs}\right)$ count rate in the $662 \mathrm{keV}$ photopeak

The general form of the algorithms derived for the sources detected at the SRS is written as:

$$
S=A-K B=\sum_{E_{1}}^{E_{2}} C R(E)-K \sum_{E_{3}}^{E_{4}} C R(E)
$$

where:

$S=$ source photopeak count rate, $E_{1}$ and $E_{2}$ bracket the photopeak, and $E_{3}$ and $E_{4}$ bracket the spectral background.

In each of the algorithms, $K$ is the ratio of the source photopeak window to the background window computed from data collected where no man-made sources are present.

$K$ is defined as:

$$
K=\frac{\sum_{E_{1}}^{E_{2}} C R(E)}{\sum_{E_{3}}^{E_{4}} C R(E)}=\frac{A}{B}
$$

$K$ is derived from the data measured over the background area at the end of each flight to minimize the effects of airborne radon-222 and minor system characterization differences between flights. 


\subsection{Contouring}

The results of the algorithms described are displayed as isocount rate contours superimposed on a 1987 United States Geographical Survey map of the southwest SRS area. The processed contour images were also entered into the Geographic Information System (GIS) for geo-referencing and future use.

Prior to entry into the GIS, the contours are computer -generated by connecting points $(x, y, z)$, when $z$, the photopeak count rate of the source of interest at position $(x, y)$, lies within a specified count rate interval. The photopeak count rate levels for the sources detected at the SRS site are given in Table 1 . The photopeak count rates were derived from the calculated uncertainty in the data described in the next section. The lowest contour level is generally derived from the uncertainty in counting a particular source of radiation. The lowest contour level is some multiple of the calculated uncertainty. Any value less than this lowest level is attributed to statistical variations; the source presence is regarded as undetectable. Sometimes significant data can be shrouded by that statistical variation depending on the choice of the lowest level. It is often useful to adjust this lowest level of the activity so that low-level radiologic variations are enhanced. Usually, the lower level is chosen to enhance variations such as those found between natural background and man-made activity significantly reduced by soil moisture, water, heavy vegetation, etc.

\begin{tabular}{|c|c|c|c|c|c|}
\hline $\begin{array}{l}\text { Letter } \\
\text { Label }\end{array}$ & $\begin{array}{c}\text { Total \& } \\
\text { Natural } \\
\text { Terrestrial }\end{array}$ & $\begin{array}{l}\text { Man-Made } \\
\text { Terrestrial }\end{array}$ & ${ }^{60} \mathrm{Co}$ & ${ }^{137} \mathbf{C s}^{\mathrm{a}}$ & ${ }^{214} \mathrm{Bi}$ \\
\hline$\overline{\mathrm{A}}$ & 2,900 & 500 & 40 & 66 & 30 \\
\hline B & 6,800 & 4,000 & 180 & 180 & 65 \\
\hline $\mathrm{C}$ & 15,600 & 16,000 & 780 & 800 & 300 \\
\hline $\mathrm{D}$ & 48,700 & 64,000 & 3,930 & 4,000 & 1,400 \\
\hline $\mathrm{E}$ & 87,400 & 256,000 & 18,300 & 18,600 & 6,500 \\
\hline F & 300,000 & & & & \\
\hline
\end{tabular}

\subsection{Data Uncertainty}

The uncertainty, $\sigma_{C R}$, in the count rate generated by the algorithms previously discussed is described in Appendix $\mathrm{C}$ of the 1986 survey report. ${ }^{10}$ The general equation for $\sigma_{C R}$ is: 


$$
\sigma_{C R}=\sqrt{K_{1}^{2} \cdot \sum_{E_{1}}^{E_{2}} \operatorname{Counts}_{E}+K_{2}^{2} \cdot \sum_{E_{3}}^{E_{4}} \operatorname{Counts}_{E}+\ldots+K_{i}^{2} \cdot \sum_{E_{n-1}}^{E_{n}} \operatorname{Counts}_{E}}
$$

Some multiple, $n$, of the standard deviation $\sigma_{C R}$, is chosen to separate source activity from statistical fluctuations in counting the source of interest at a particular confidence interval. All statistical excursions of various algorithm results were evaluated to determine their origins. Generally, several contour maps are generated for a specific radionuclide with selected values of $n$ that ensure the low-level trends in man-made source activity are not suppressed. Also, it is often useful to choose both the lowest level and the level intervals to show variations in the natural environment (vegetation, waterways, land use, etc.) and to verify the dynamic range of sensitivity of the detector system. Use of multiples of the calculated uncertainty, i.e., $n \sigma$, allows a quantitative means of evaluating a variety of data circumstances. This level is adjusted in most cases for the contour levels of total natural and man-made activity. Values of $n \sigma$ where $n=3$ for sources previously described are listed in Table 2.

\begin{tabular}{|c|l|c|c|}
\hline \multicolumn{2}{|c|}{ Table 2. Contour Map Minimum Count Rates or Exposure Ratec á,b.c } \\
\hline \multirow{2}{*}{ Figure } & \multicolumn{1}{|c|}{ Source } & $\begin{array}{c}\text { Minimum Level } \\
(3 \sigma)\end{array}$ & Units \\
\hline 3 & Total Terrestrial & 2,900 & $\mathrm{cps}$ \\
4 & Natural Terrestrial & 26 & $\mathrm{mrem} / \mathrm{yr}$ \\
5 & Man-Made and & 500 & $\mathrm{cps}$ \\
& Excess Natural ${ }^{214} \mathrm{BI}$ & 30 & $\mathrm{cps}$ \\
6 & Excess ${ }^{214} \mathrm{Bi}$ & 3 & $\mathrm{mrem} / \mathrm{yr}$ \\
7 & 60Co & 4 & $\mathrm{mrem} / \mathrm{yr}$ \\
\hline
\end{tabular}

${ }^{a}$ The mrem $/ \mathrm{yr}$ were calculated using a time conversion of $8.76 \mathrm{mrem} / \mathrm{yr} / \mu \mathrm{R} / \mathrm{h}$ (see Reference 2).

b Total Count Rate and Natural Terrestrial Count Rate minimum contour was chosen at $2,900 \mathrm{cps}=26 \mathrm{mrem} / \mathrm{yr}$ based on observed levels rather than on counting statistics.

c Total terrestrial and man-made isopleths were used primarily to establish the spatial distribution and relative intensity of detected gamma emitters; no conversions were applied to these count rate data.

The lowest contour level, A, in Table 1 for all the sources is $3 \sigma_{C R}$, which implies a $99.7 \%$ level of confidence that a detection above this level is real. Also a real source, whose mean count rate is $3 \sigma$, will be detected only $50 \%$ of the time. It follows that sources with larger count rates are more readily detected. Spectral analysis of anomalous activity is the best means to establish confidence that an anomaly is real. 


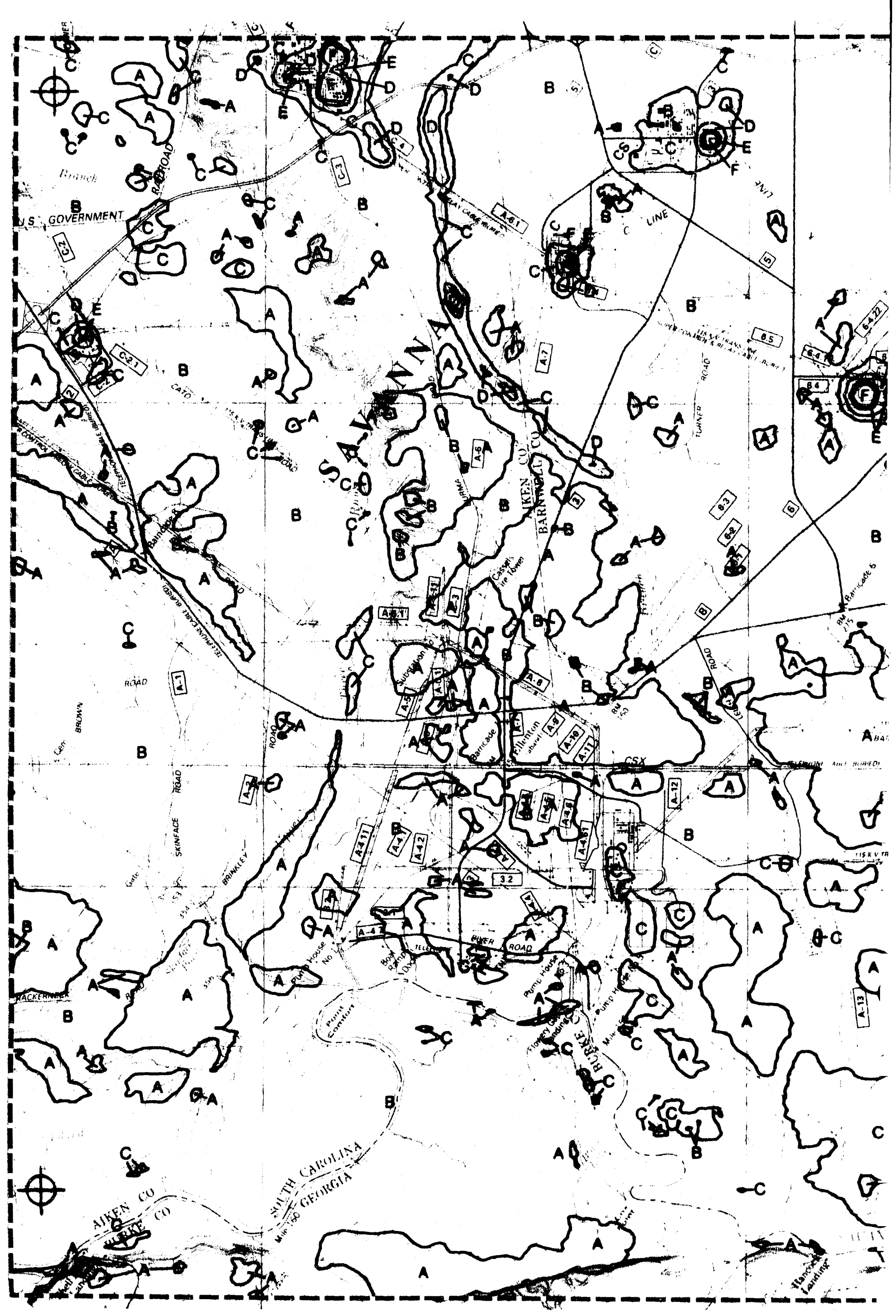



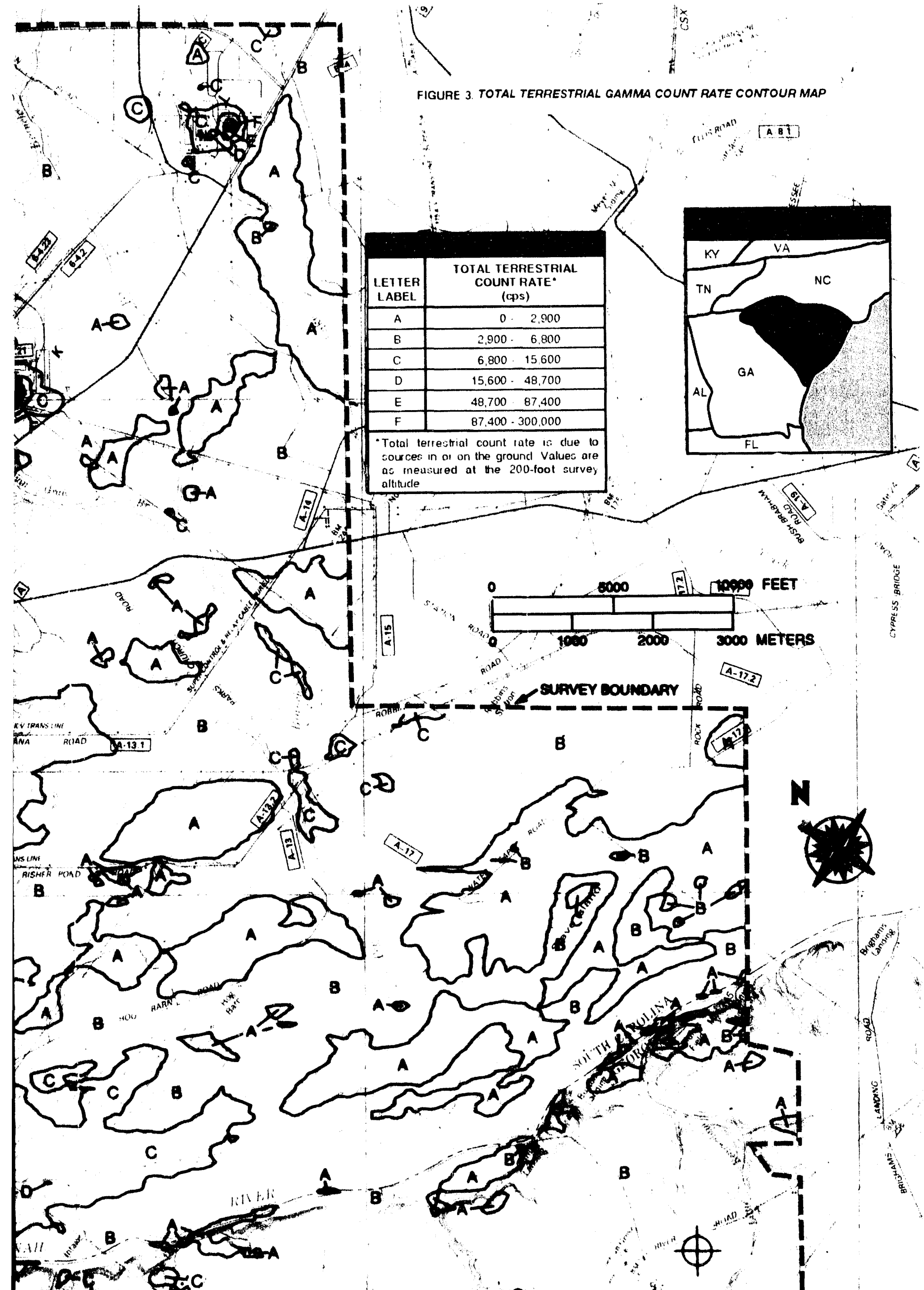


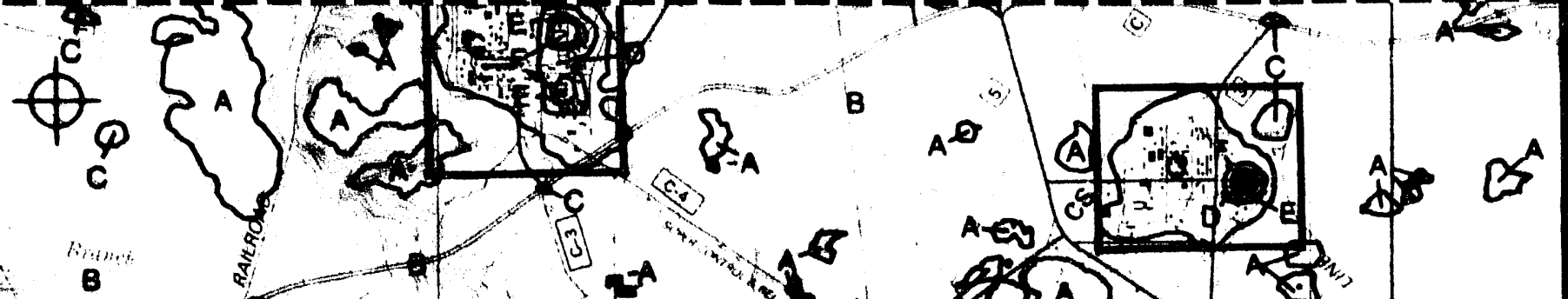
$+60$

29
0

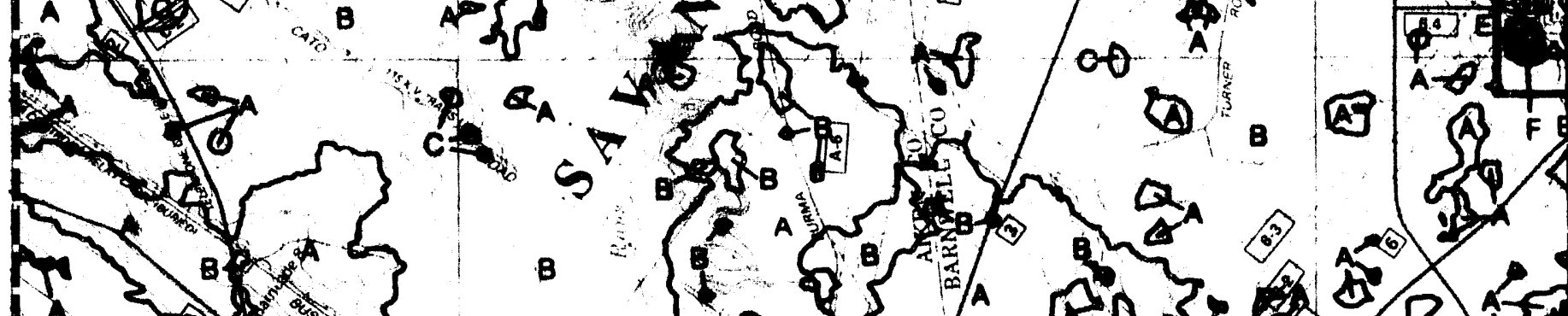

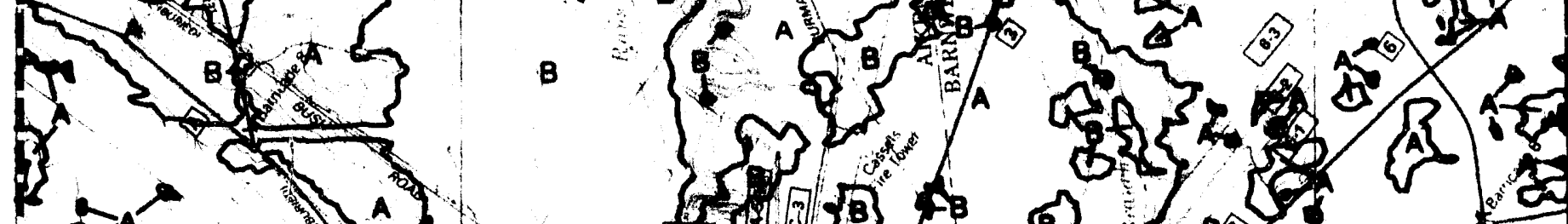

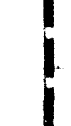
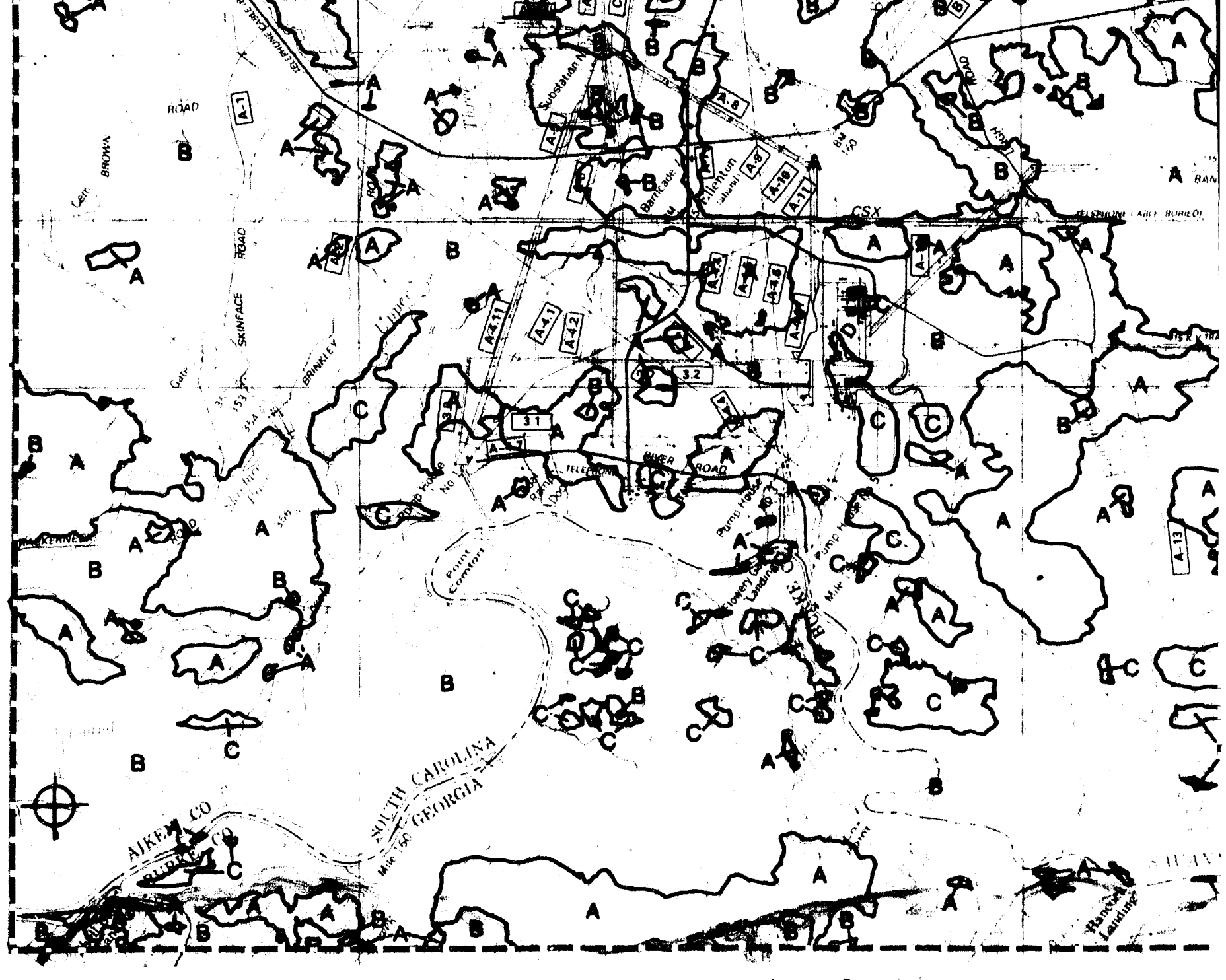


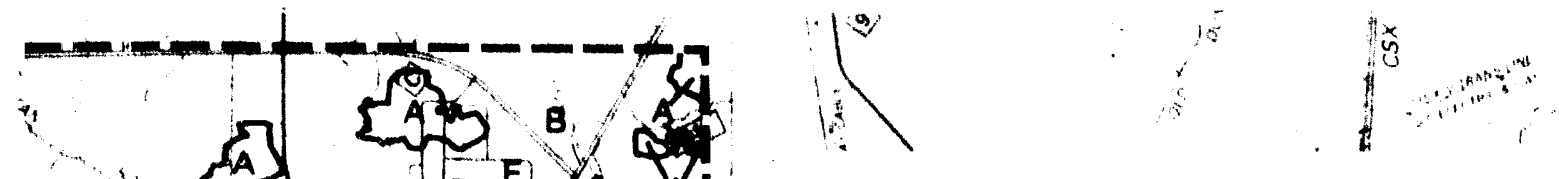

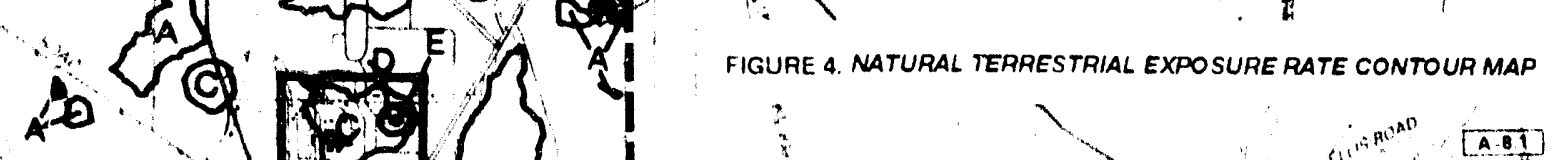

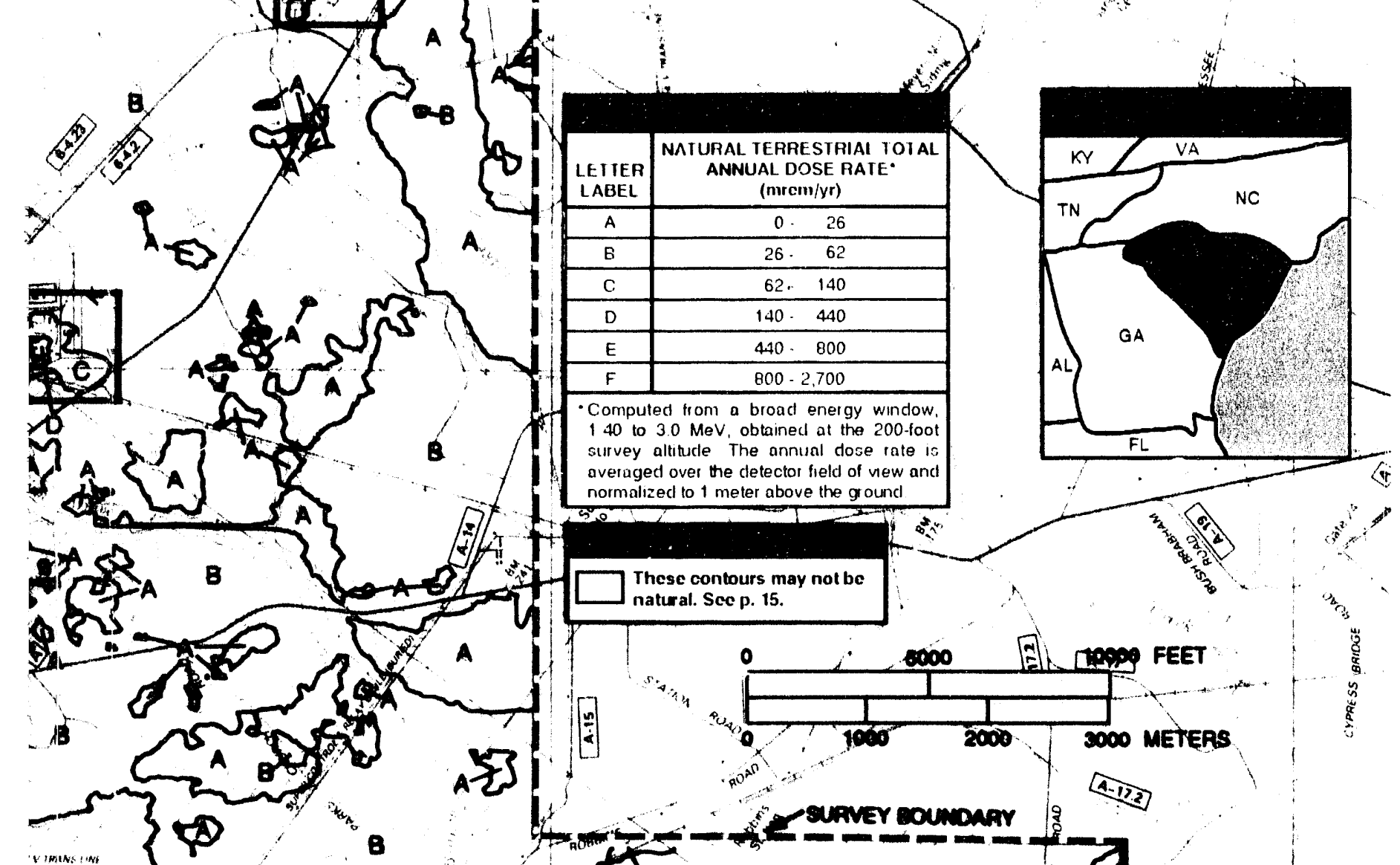

$\left\{\begin{array}{l}\infty \\ N A\end{array}\right.$

NA

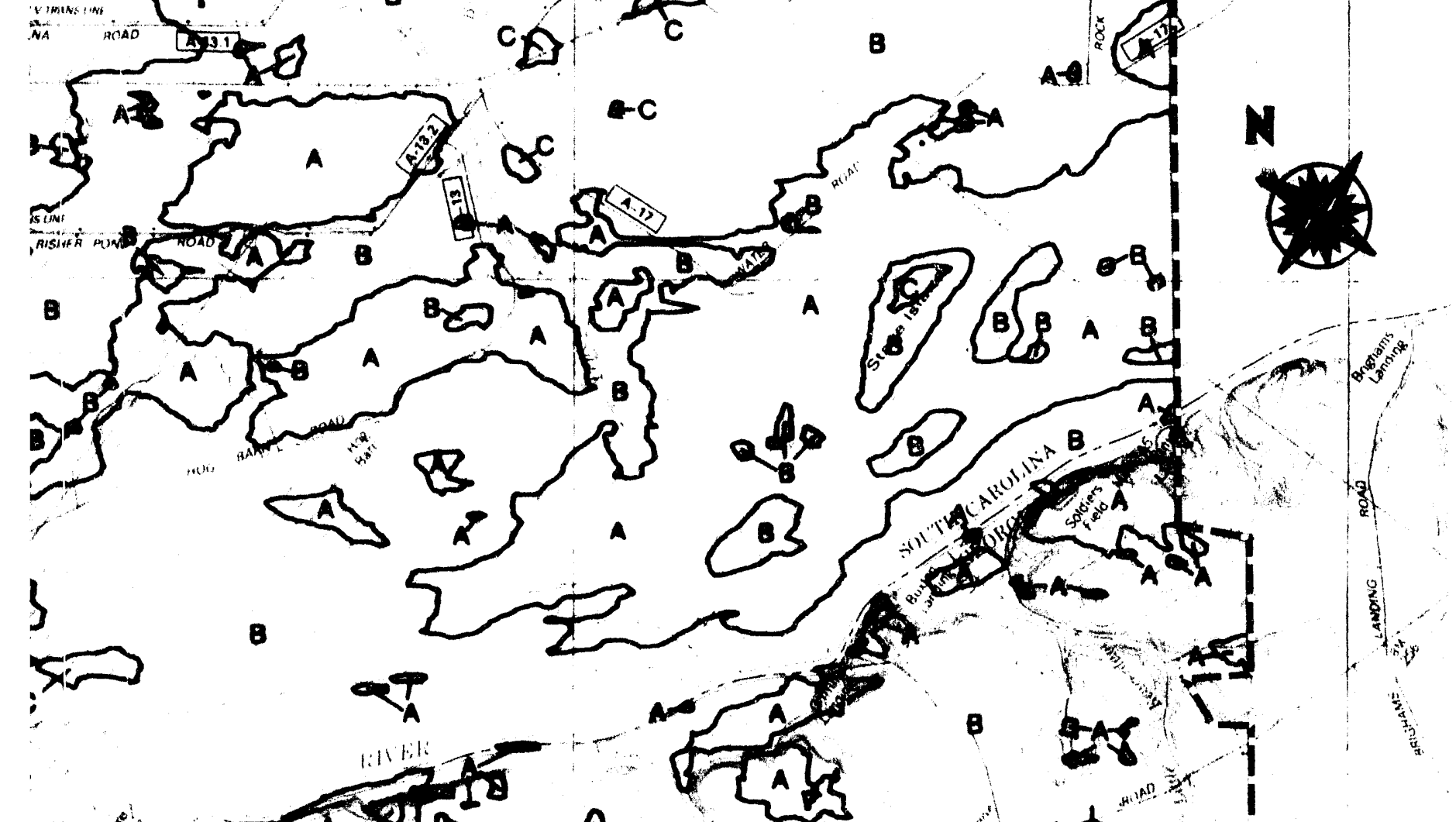

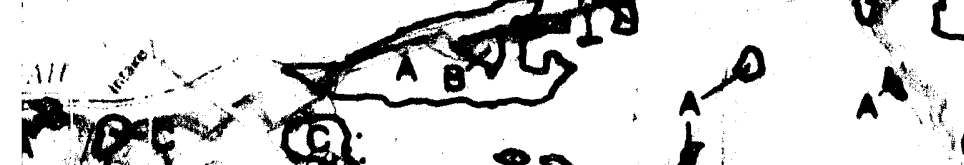

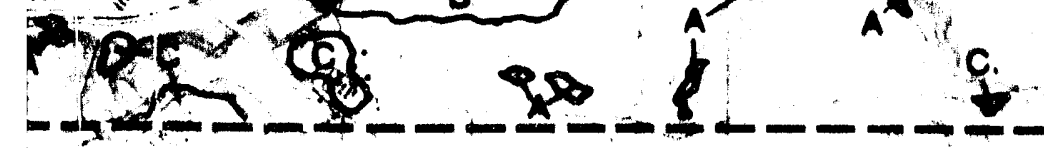

$\rightarrow \rightarrow \theta^{\prime}$

Dab or map: 1007 


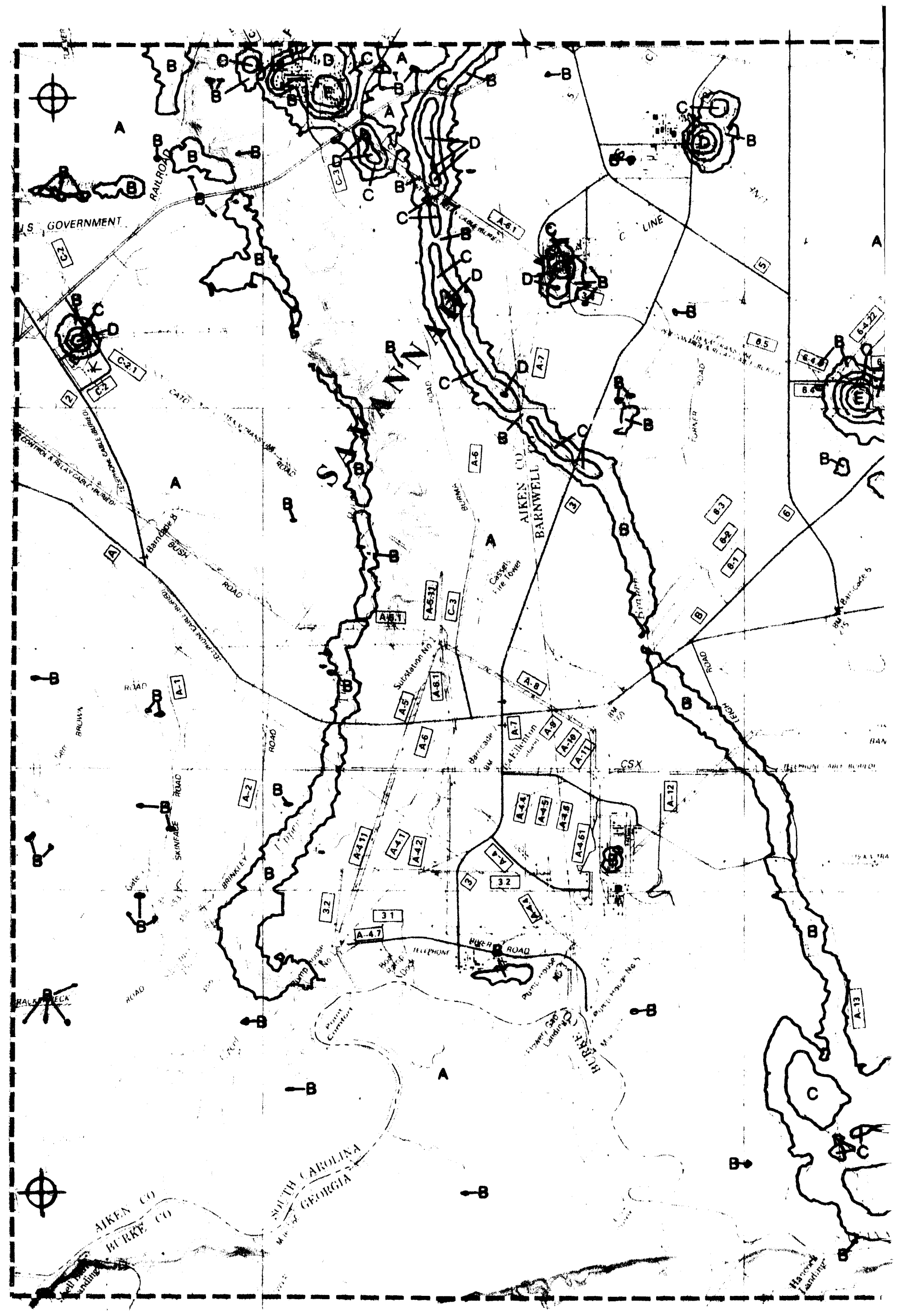




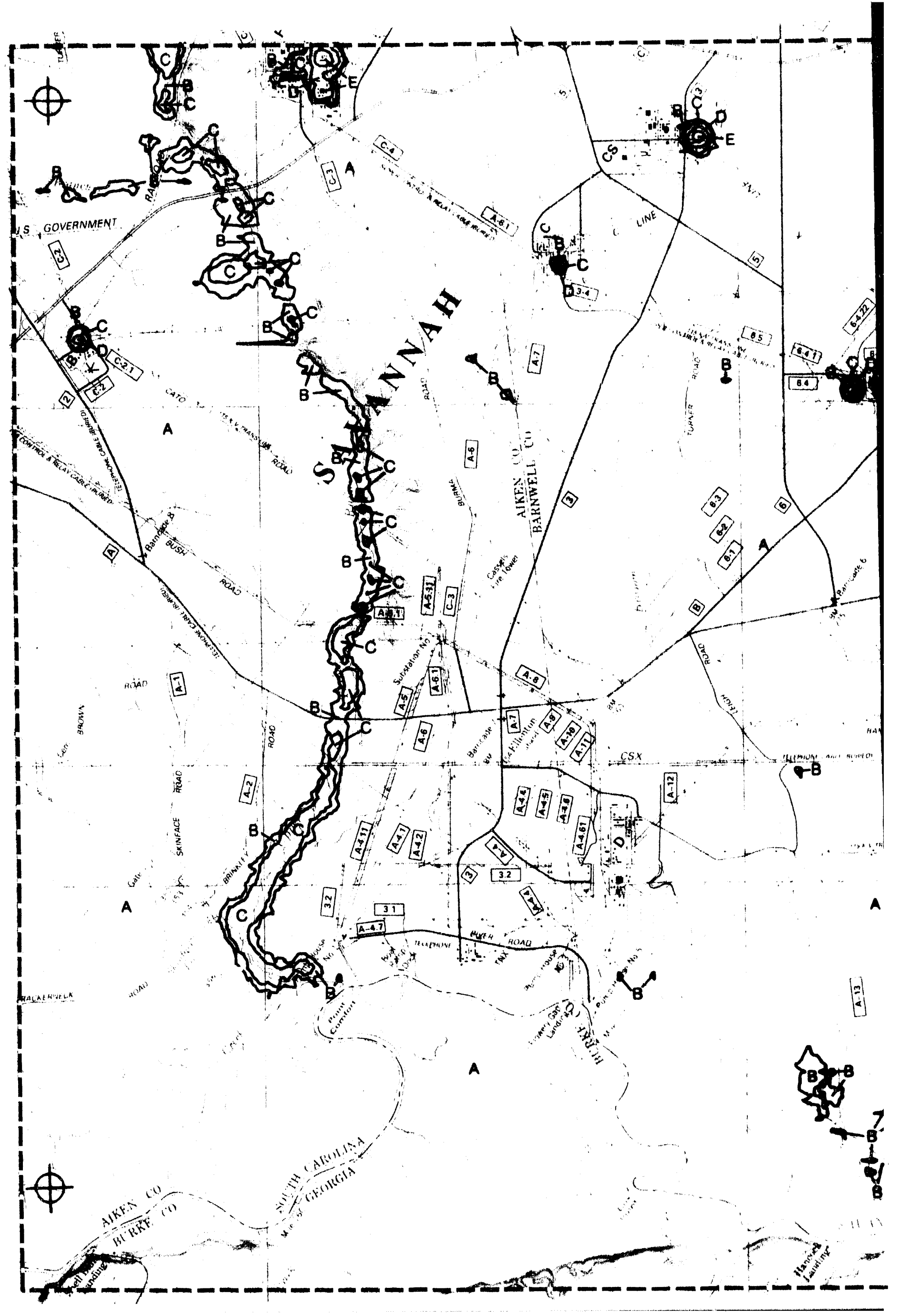




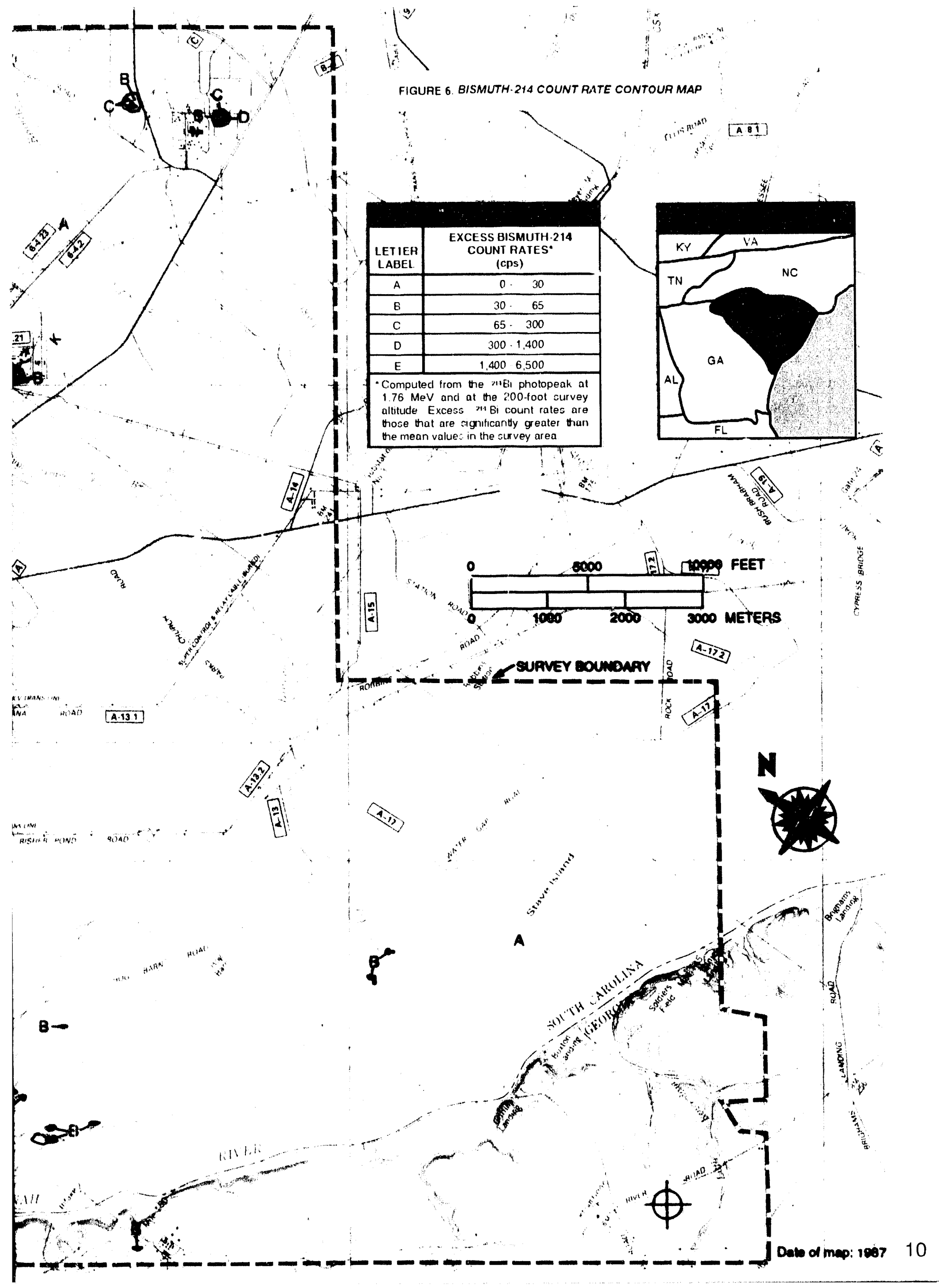




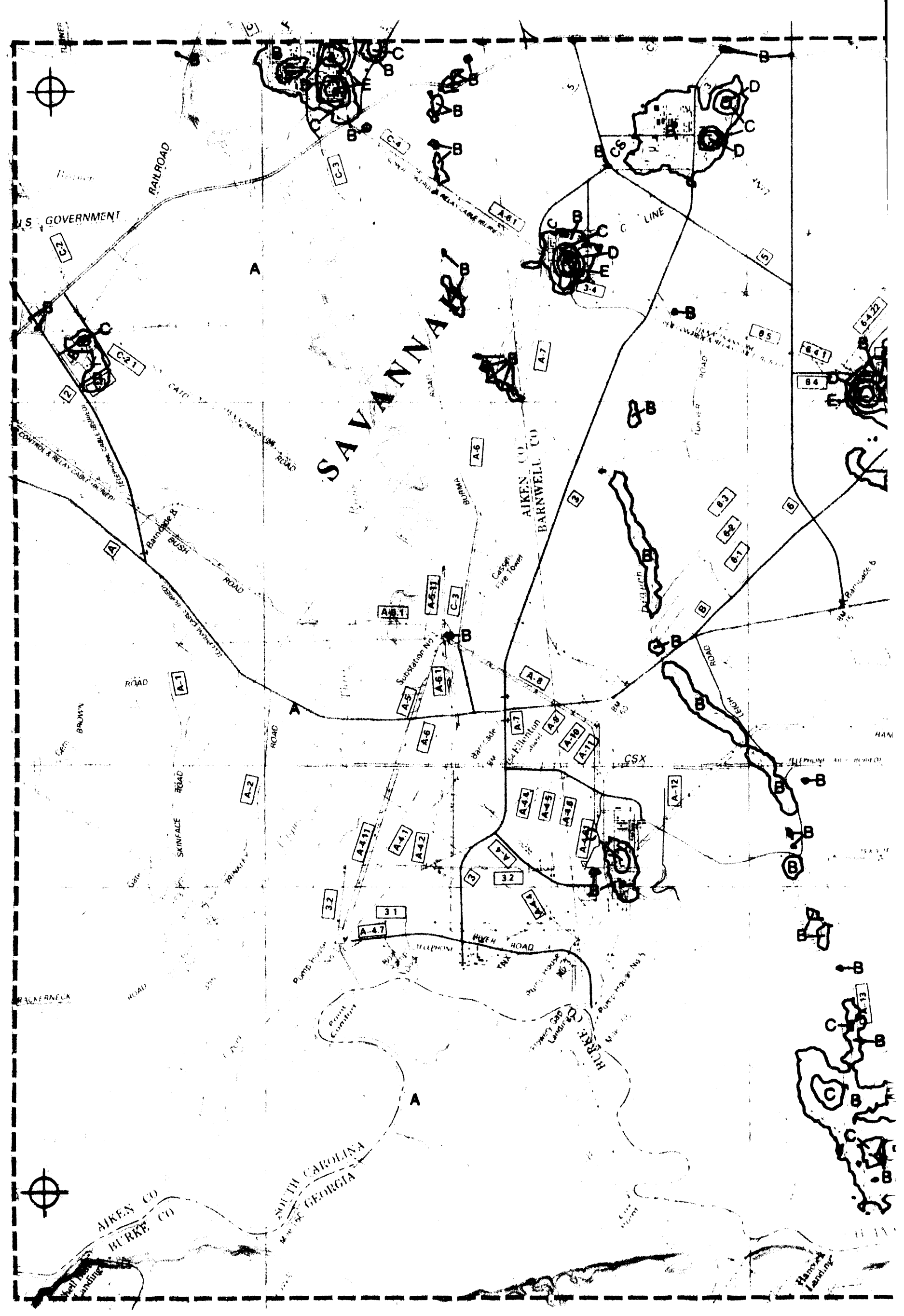




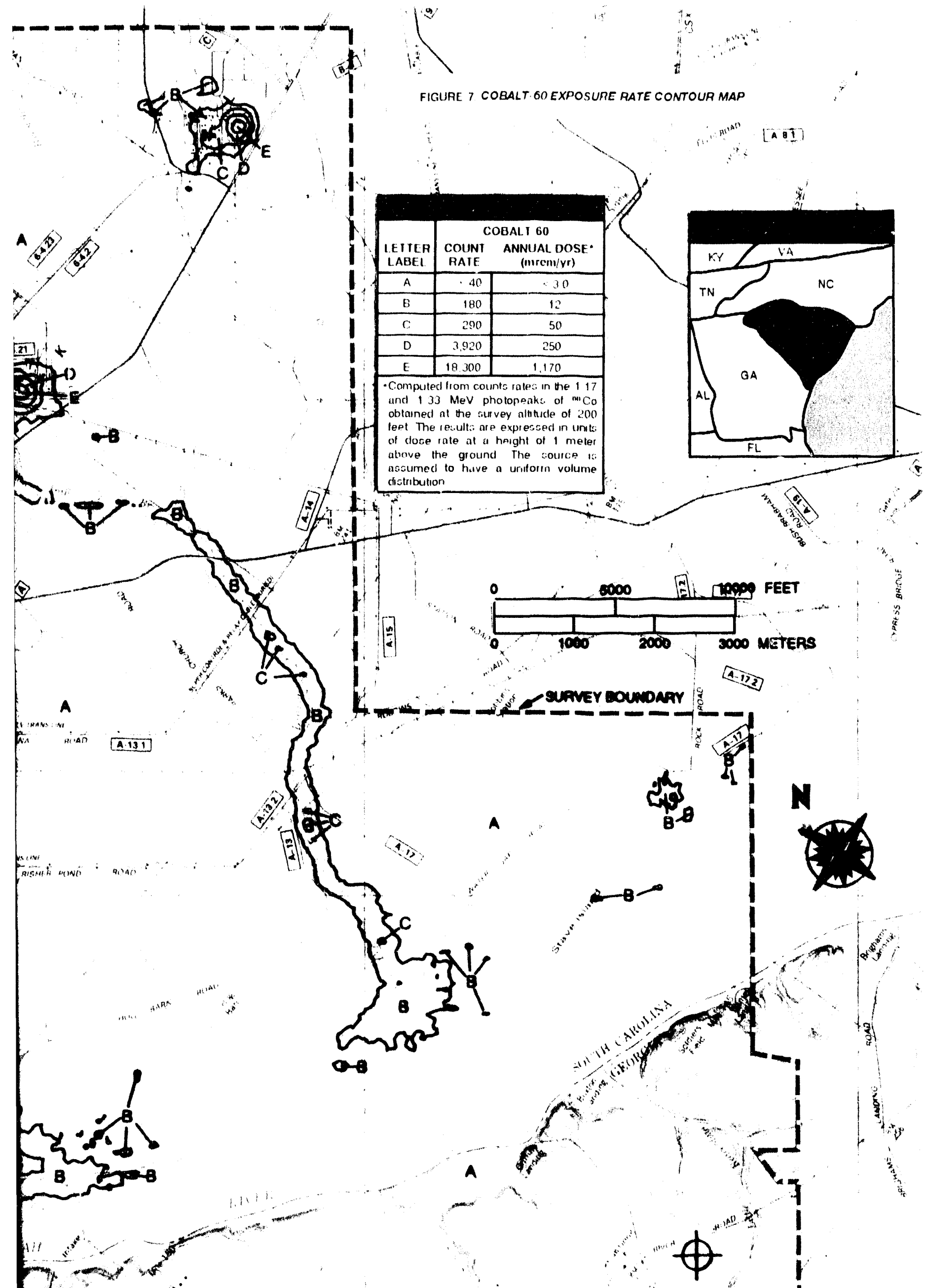

I Dab of mea: 1007 


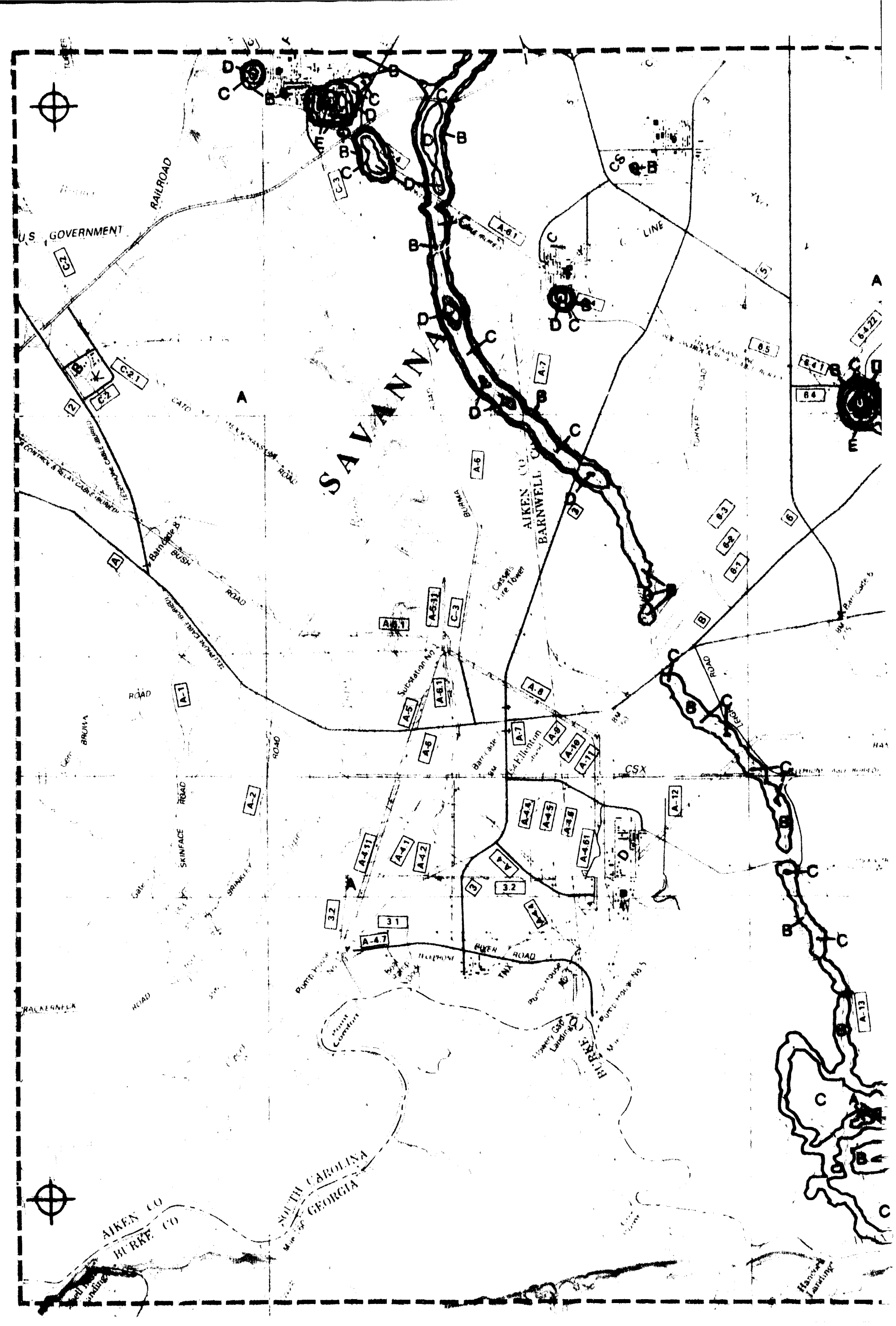




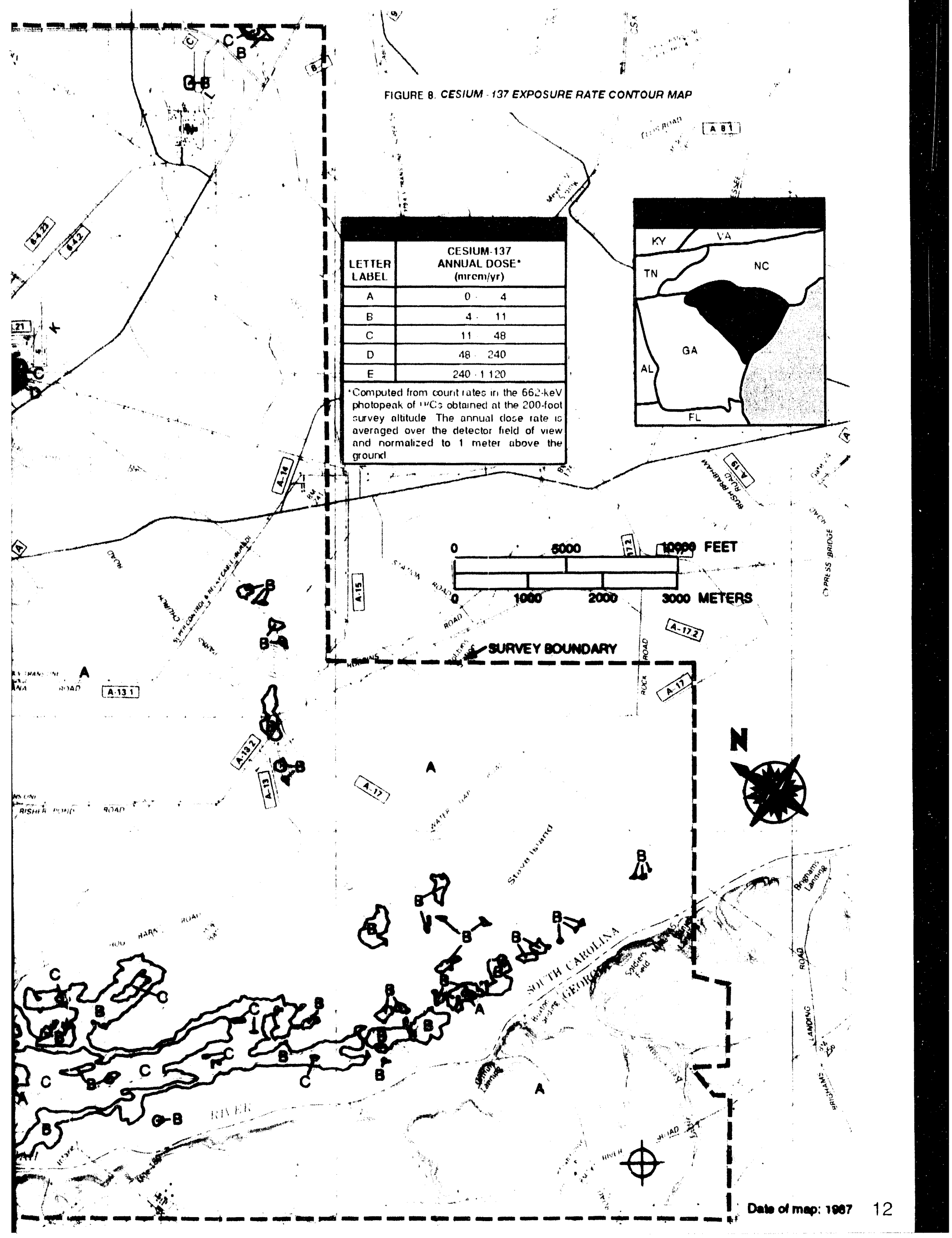




\subsection{Other Uncertainties}

Other uncertainties exist that cannot be evaluated simply. These are a result of the following:
A. Uncertainty in assumptions needed to apply predetermined count rate to activity conversion factor.
B. Uncertainty in the distribution of the source of inceres :.
C. Uncertainty in measuring contributions of airborne radionuclides.
D. Uncertainty in measuring the media attenuation (terrain cover, soll moisture, etc.).

\subsection{Spatial Resolution of the Detector System}

Sources detected by aerial systenis will appear to be spread over a much larger area than that shown by ground-based measurements. Usually, count rates are converted to activity on or in the soil and normalized to $1 \mathrm{~m}$ above ground level (AGL), but only as a large-area average. A data point collected each second of flight is averaged over an area with a diameter that may be as much as three times that of the detector platform altitude. The size of the field of view is a function of the gamma ray energy, gamma ray origin, and the detector response. Activity inferred from aerial data for a source uniformly distributed over a large area compared to the field of view of the detectors is very good and generally agrees witl groundbased measurements. However, activity for a point source, a line source, or any source activity less than the detector field of view will be underestimated, sometimes by orders of magnitude. When these occasions arise, the aerial data simply serve to locate and identify such sources.

The man-made activity detected in the three survey areas is likely confined to the first or second center contour intervals. Ground-based measurements would be necessary to accurately establish the contamination boundaries. The aerial data would serve as a useful guide.

\subsection{Total Uncertainty}

The total uncertainty may be quite large in some data points due to variations in the parameters previously described. To minimize the uncertainty, the detector system is continually calibrated and/or characterized throughout each survey.

\subsection{Count Rate Conversion}

A secondary process is to convert count rates measured at survey altitude to activity on or in the soil; this methodology is explained in detail in prior reports. ${ }^{10}$ Once the soil sampling data collected by SRS personnel become available, a table of conversion factors will be derived, perhaps based on the sampling results. This may provide a better source distribution model and, hence, a better estimate of the activity on or in the soil. However, calculated factors will be provided that convert count rates to activity of sources uniformly distributed in the soil, exponentially distributed in the soil, distributed on the soil surface, and 
unshielded point sources. These conversion factors were generated to bracket the possible source distributions that may exist in the surveyed area.

Conversion factors were applied to the count rates generated by the algorithms to yield the annual dose rate (mrem/yr) for selected sources. The dose rates for each source were combined with position information to generate isoradiation contour maps. Table 1 lists the isoradiation contour maps generated for the detected activities.

\subsection{RESULTS}

Count rates due to gamma rays of both elevated naturally-occurring and man-made radionuclides were detected over southwest area facilities, creeks, branches, creek drainage basins, and adjacent land areas, along with the typical naturally-occurring gamma emitting radionuclides. Areas where specific radionuclides were identified are listed in Table 3 (the $\mathrm{Xs}$ in the source column). Figures 3 through 8 illustrate isoradiation contour maps of the detected sources. The detecied man-made sources are likely traceable to SRS operations.

\begin{tabular}{|l|c|c|c|c|}
\hline \multicolumn{4}{|c|}{ Table 3. Distribution of Sources in tije Southwest Area } \\
\hline \multicolumn{1}{|c|}{ Areas/Facilities } & \multicolumn{4}{c|}{ Source } \\
\cline { 2 - 5 } & $137 \mathrm{Cs}$ & ${ }^{60} \mathrm{Co}$ & ${ }^{214} \mathrm{Bi}$ & $234 \mathrm{mPa}$ \\
\hline Fourmile Branch & $\mathrm{X}$ & $\mathrm{X}$ & & \\
Pen Branch & $\mathrm{X}$ & $\mathrm{X}$ & $\mathrm{X}$ & \\
Upper Three Runs Creek & & & $\mathrm{X}$ & \\
Central Shops & & $\mathrm{X}$ & $\mathrm{X}$ & $\mathrm{X}$ \\
C Area & & $\mathrm{X}$ & $\mathrm{X}$ & \\
F Area & $\mathrm{X}$ & & $\mathrm{X}$ & \\
K Reactor & $\mathrm{X}$ & $\mathrm{X}$ & $\mathrm{X}$ & \\
L Reactor & $\mathrm{X}$ & $\mathrm{X}$ & $\mathrm{X}$ & \\
B Area & & & $\mathrm{X}$ & $\mathrm{X}$ \\
D Area & & $\mathrm{X}$ & $\mathrm{X}$ & \\
Drainage Basin from & $\mathrm{X}$ & $\mathrm{X}$ & $\mathrm{X}$ & \\
Fourmile and Pen Branches & & & & \\
\hline
\end{tabular}

Twenty-six locations were specifically investigated where significant levels of man-made activity were detected; i.e., all areas where detected values were greater than the minimum level described previously. Figure 9 gives a diagram of those locations. The activities of both ${ }^{214} \mathrm{Bi}$ and ${ }^{137} \mathrm{Cs}$ were in excess of typical background levels. The abundance of ${ }^{214} \mathrm{Bi}$ in the SRS environment can be separated into two categories: that in which the ratio of ${ }^{214} \mathrm{Bi}$ to thorium and its daughters is typical of the natural background isotope mix and that in which 
its ratio is in excess of the expected ratio. Generally, such a deviation indicates an increase in the abundance of ${ }^{214} \mathrm{Bi}$. Spectral data were selected at these locations to attempt to identify and establish the distribution of specific gamma emitting radionuclides. As indicated by the spectral analysis, contributors to the man-made activity were cobalt-60, cesium-137, and protactinium-234m (Figure 10).

Elevated gamma ray activity of naturally-occurring uranium-238 ( $\left.{ }^{238} \mathrm{U}\right)$ and progeny was detected along segments of Upper Three Runs Creek. According to SRS officials, Upper Three Runs Creek flows through an area with ${ }^{238}$ U levels higher than those typically found throughout the SRS site.

The distribution of the natural and total terrestrial radiation levels is consistent with values measured in adjacent areas during previous surveys. The typical background value of these activities in areas where no man-made contamination exists is $50-70 \mathrm{mrem} / \mathrm{yr}$.

Some nuclear, industrial areas contain dominating isotopes at high fluence rates that may mask the presence of other isotopes. So, the contours and spectra from these areas may be misinterpreted in some cases. The natural dose appears large over some of the industrial areas and should not be interpreted literally, but rather interpreted from the mathematical definition (Equation 2). Excess ${ }^{214} \mathrm{Bi}$ (both natural and man-made) also occurs in the industrial and non-industrial areas. The occurrence of ${ }^{214} \mathrm{Bi}$ may not be substantiated in the energy spectra, as presented, because of dominating ${ }^{60} \mathrm{Co}$. 


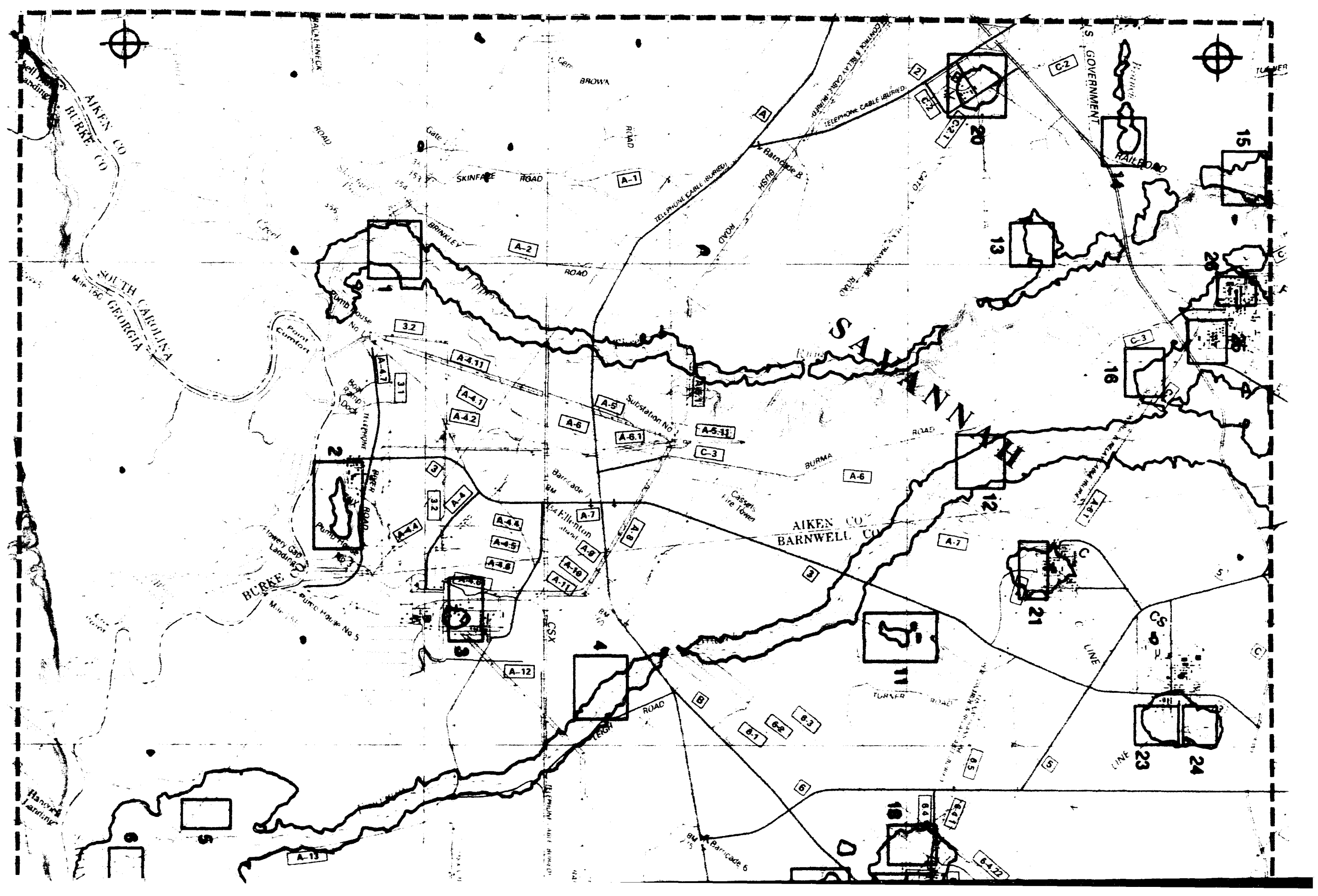




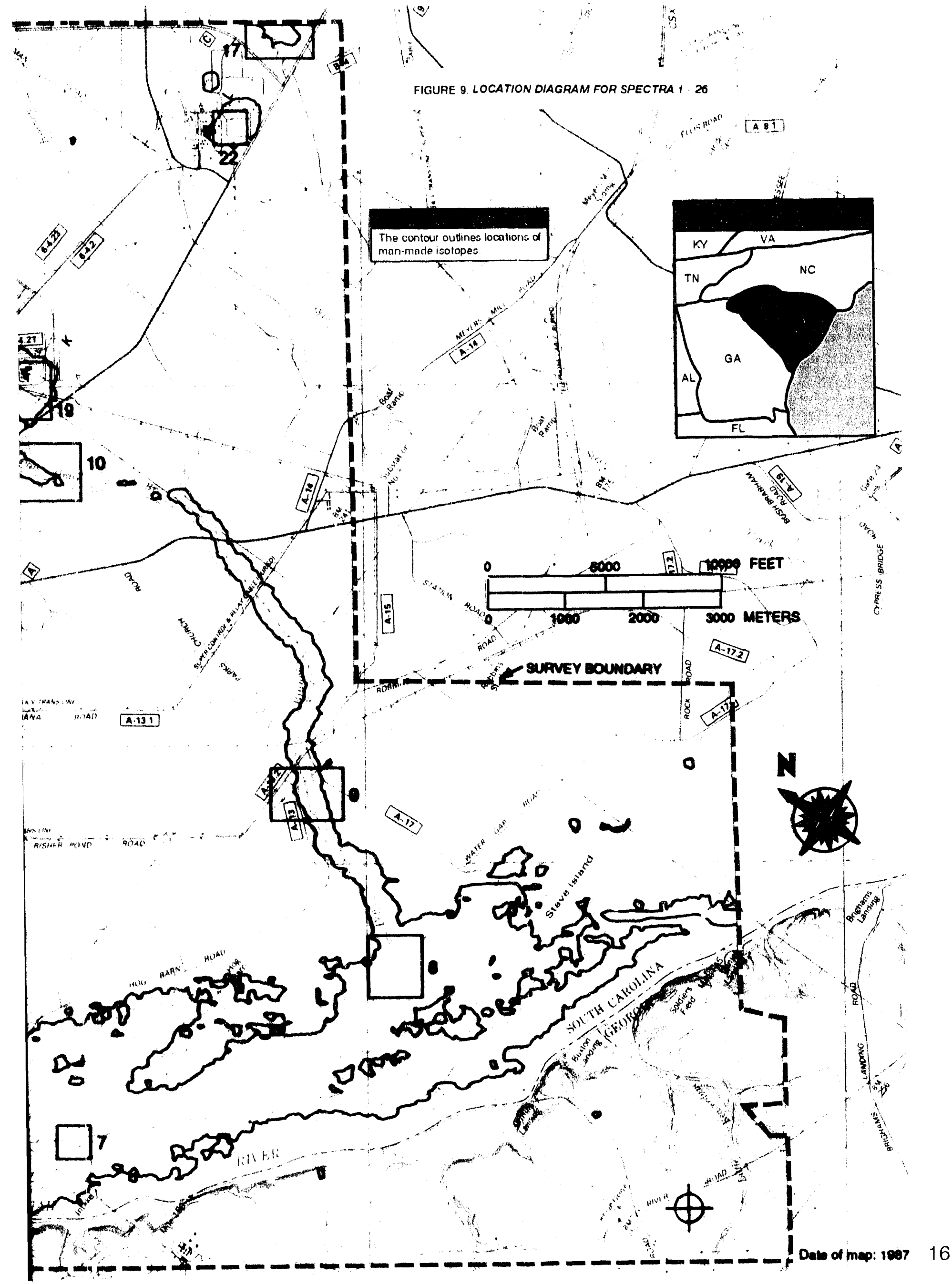



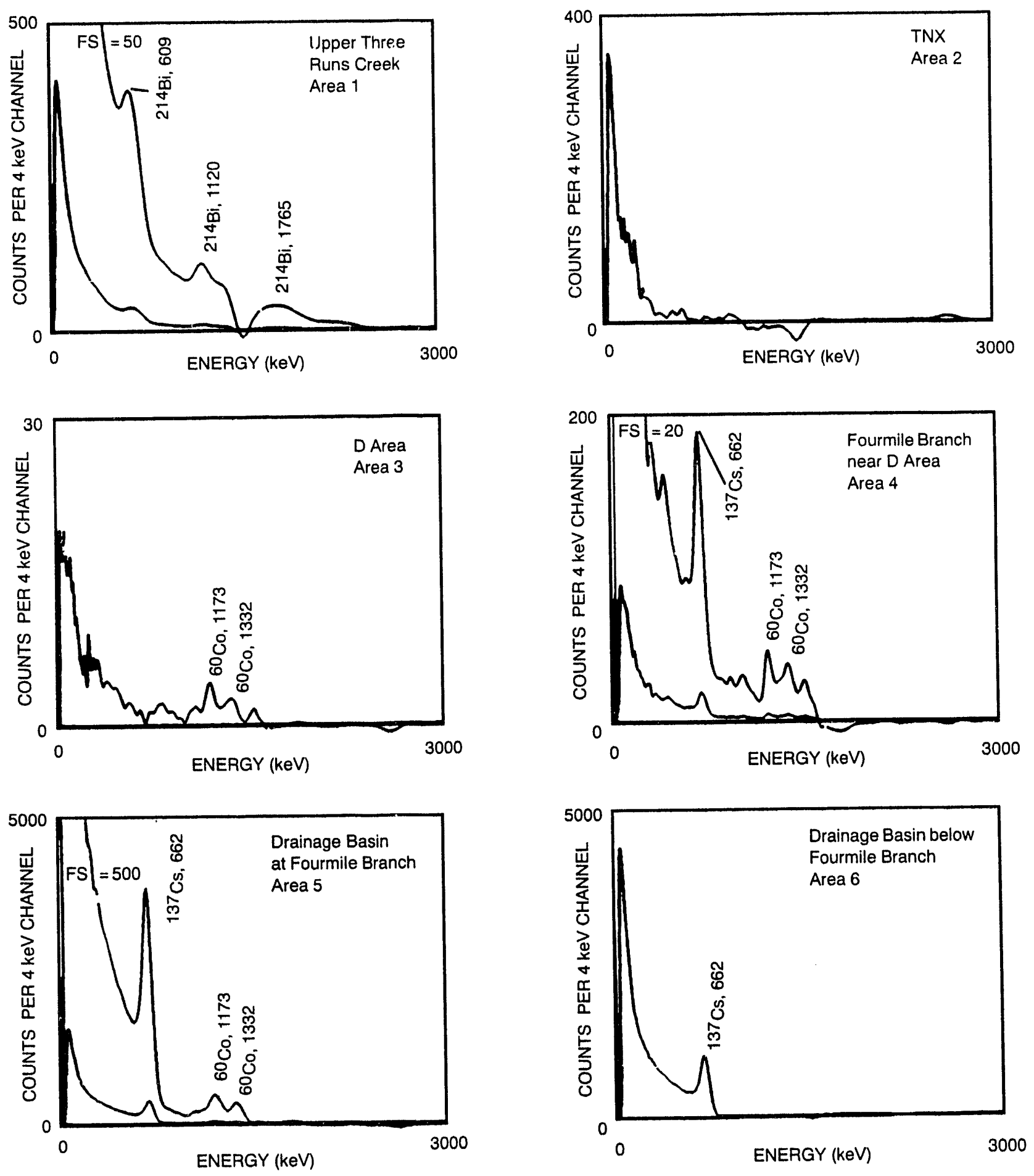

FIGURE 10. GAMMA RAY PULSE HEIGHT SPECTRA OF AREAS 1-26. Refor to Figure 9 for locations. 

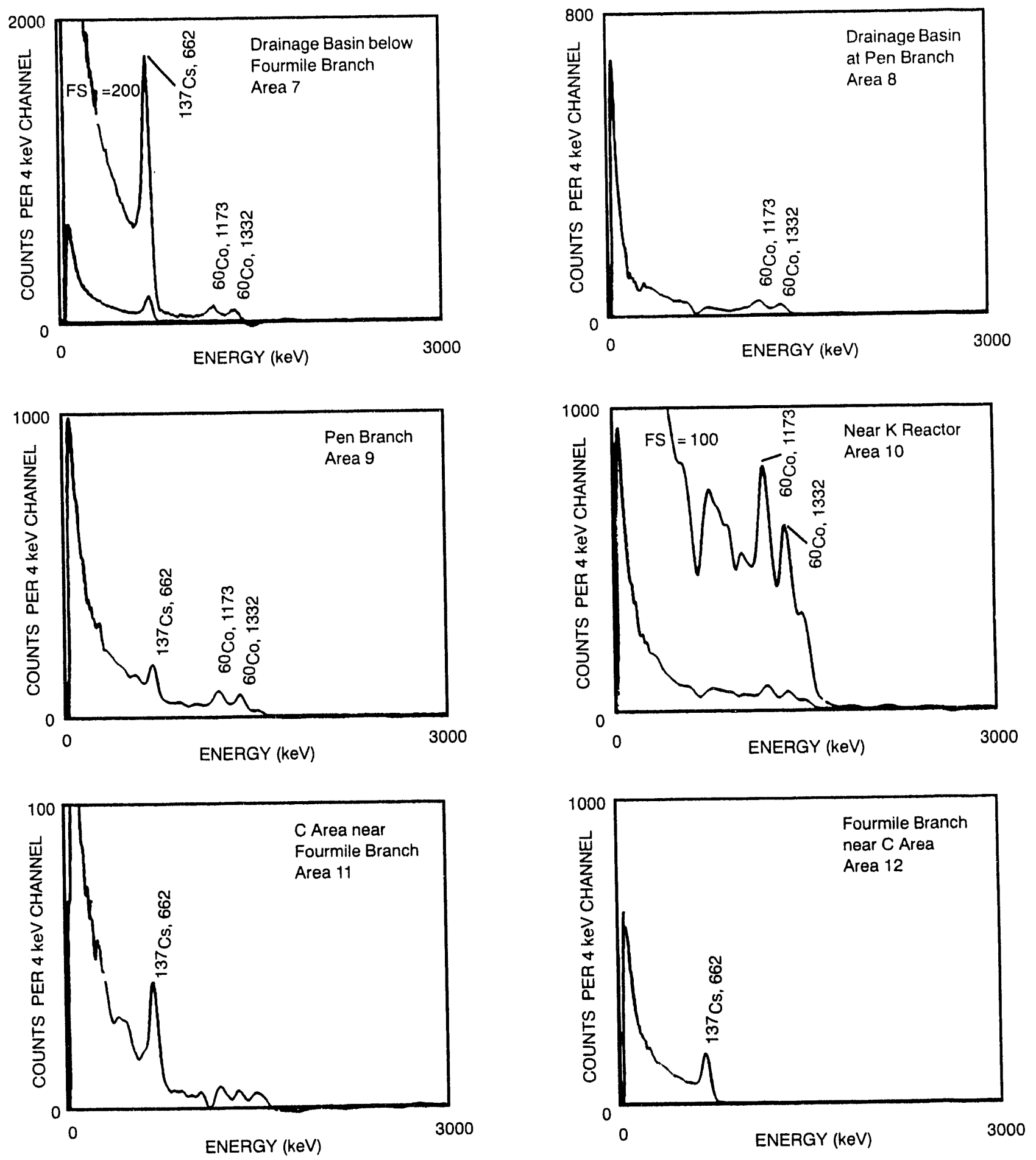

FIGURE 10. GAMMA RAY PULSE HEIGHT SPECTRA OF AREAS 1-26. Refer to Figure 9 for locations (continued). 

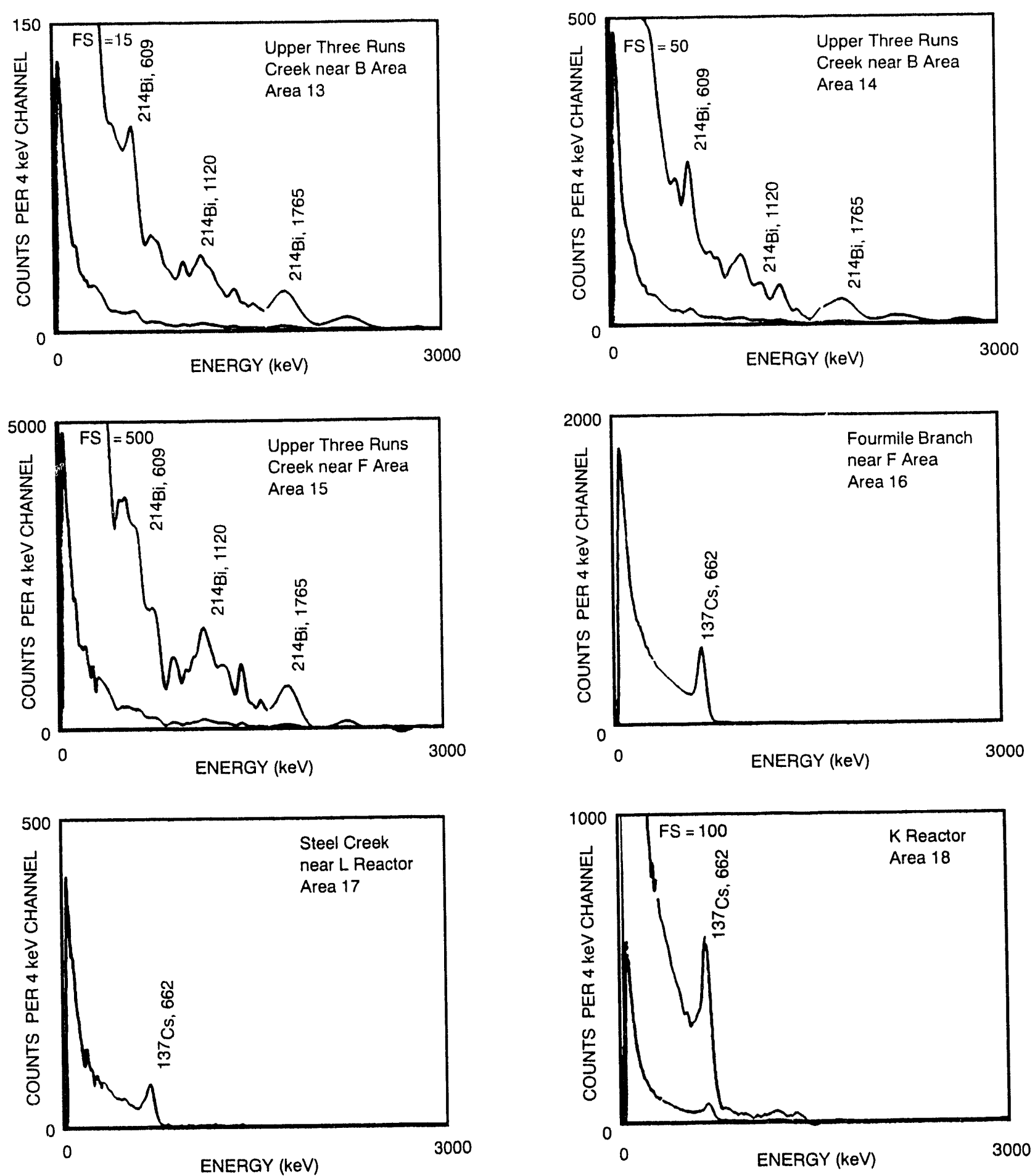

FIGURE 10. GAMMA RAY PULSE HEIGHT SPECTRA OF AREAS 1-26. Refer to Figure 9 for locations (continued). 

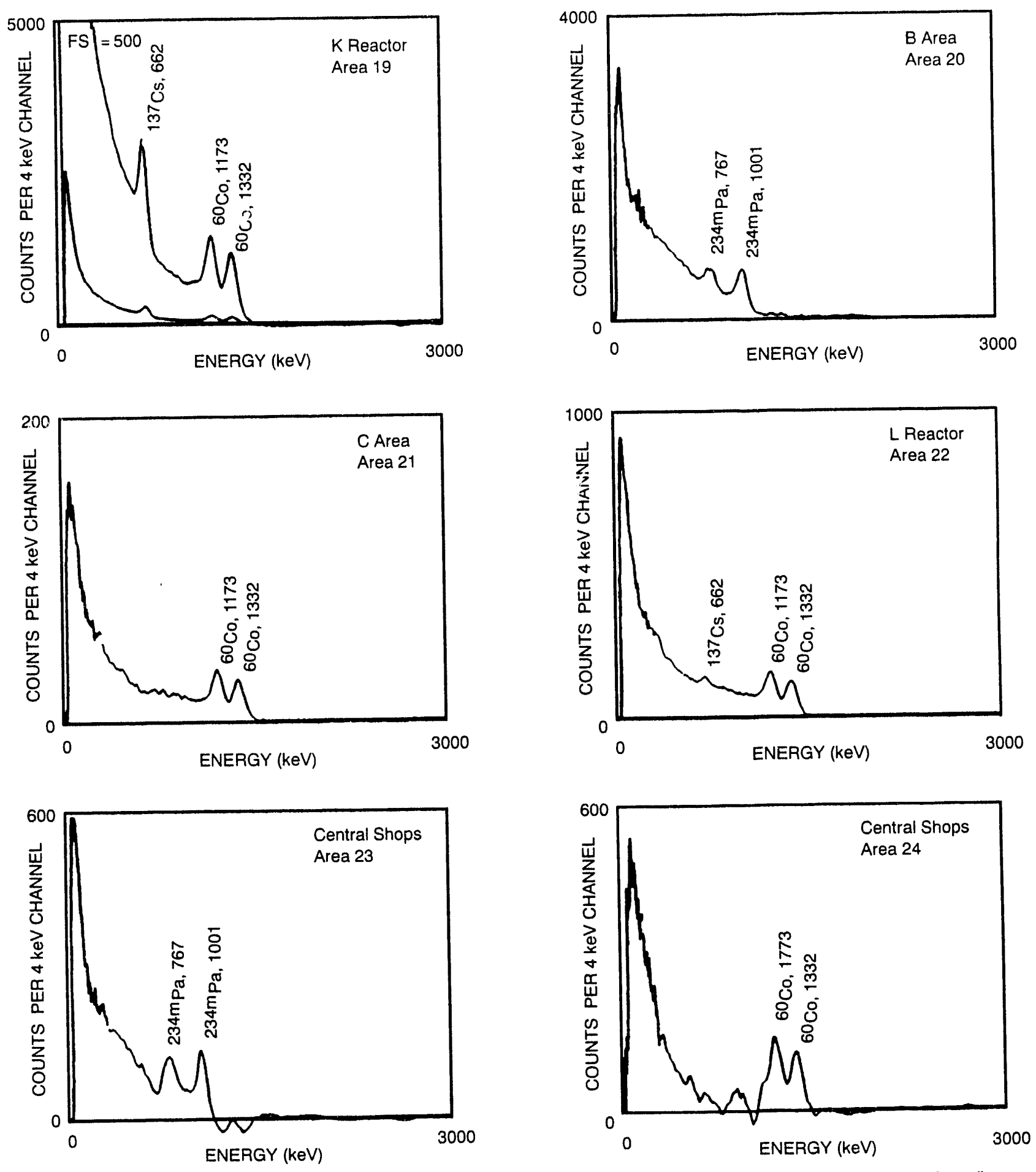

FIGURE 10. GAMMA RAY PULSE HEIGHT SPECTRA OF AREAS 1-26. Refer to Figure 9 for locations (continued). 

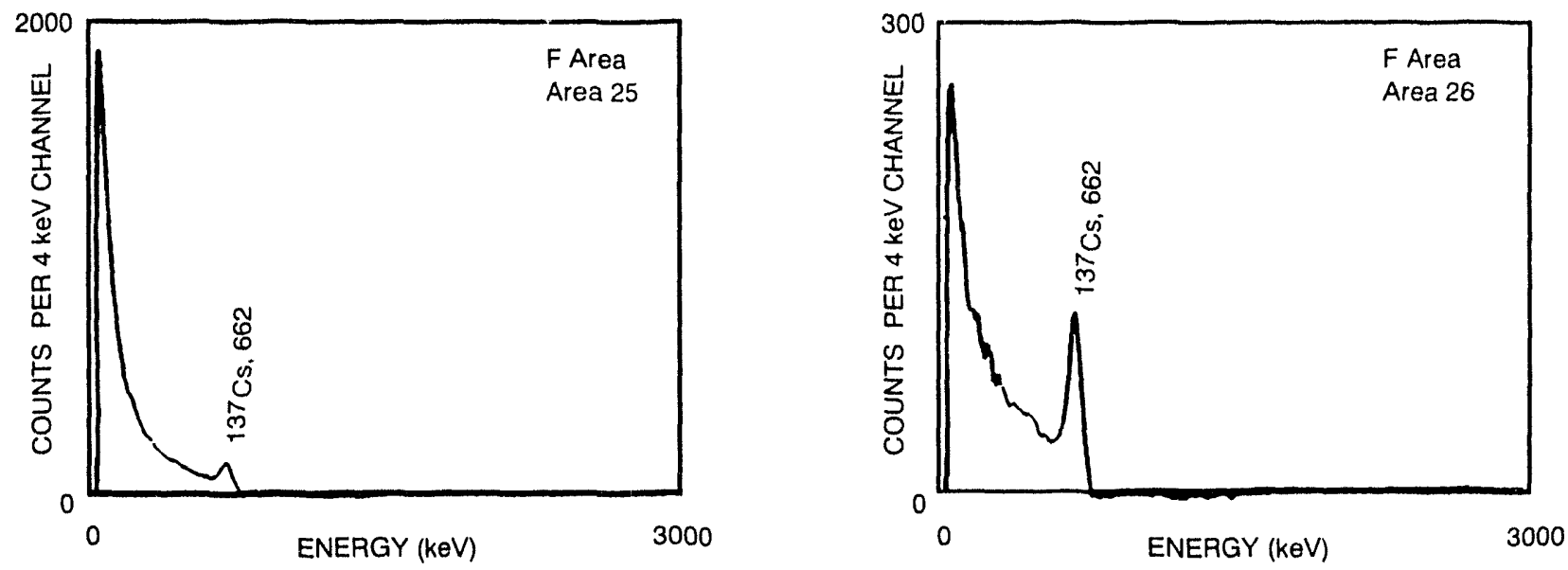

FIGURE 10. GAMMA RAY PULSE HEIGHT SPECTRA OF AREAS 1-26. Refer to Figure 9 for locations (concluded). 
APPENDIX A

\section{SURVEY PARAMETERS}

Site:

Location:

Survey Date:

Base of Operation:

Survey Coverage:

Lines Surveyed:

Line Spacing:

Survey Altitude:

Project Scientist:

Survey Aircraft:

Acquisition System:

Detector Array:
Southwestern SRS

Alken, South Carolina

24 August-8 September 1988

Bush Field, Augusta, Georgia

$106 \mathrm{sq} \mathrm{mi}{ }^{2}\left(275 \mathrm{~km}^{2}\right)$

212

$250 \mathrm{ft}(76 \mathrm{~m})$

$200 \mathrm{ft}(61 \mathrm{~m})$

E.L. Feimster

MBB BO-105 helicopter

REDAR IV

Eight 4- $\times 4-\times 16-$ in $\mathrm{NaI}(\mathrm{T} l)$ detectors $(\mathrm{Cd}-\mathrm{Pb}$ shield upper surface and sides)

Two 4-in-diameter $\times 4$-in-thick NaI(Tl) detectors Two 3-in-diameter $\times$ 3-in-thick upward-looking $\mathrm{NaI}(\mathrm{Tl})$ detectors

Data Processing:

Sources: Cesium-137:

Energy Window: 0.590 to $0.722 \mathrm{keV}$

Conversion Factor: $0.0377 \mathrm{mrem} / \mathrm{yr} / \mathrm{cps}$

Cobalt-60:

Energy Window: 1,094 to $1,394 \mathrm{keV}$

Conversion Factor: $0.065 \mathrm{mrem} / \mathrm{yr} / \mathrm{cps}$

Bismuth-214:

Energy Window: 1,574 to $1,946 \mathrm{keV}$

Total Terrestrial Activity:

Energy Window: 38 to $3,026 \mathrm{keV}$

Conversion Factor: $0.0090 \mathrm{mrem} / \mathrm{yr} / \mathrm{cps}$

Natural Terrestrial Activity:

Energy Window: 38 to $3,026 \mathrm{keV}$

Conversion Factor: $0.0090 \mathrm{mrem} / \mathrm{yr} / \mathrm{cps}$

Cosmic Ray Contribution: $33 \mathrm{mrem} / \mathrm{yr}$ 


\section{APPENDIX B}

\section{SURVEY EQUIPMENT AND PROCEDURES}

The aerial radiological measurements were made with a detector array and a data acquisition system mounted in a Messerschmitt-Bolkow-Blohm (MBB) BO-105 helicopter (Figure B-1). The detector package consisted of an array of eight sodjum lodide (thallium-activated), NaI(Tl), detectors. Each detector was comprised of a photomultiplier tube coupled to a $\mathrm{NaI}(\mathrm{Tl})$ crystal which was $4 \times 4 \times 16 \mathrm{in}$. Two equipment pods, each containing four detectors, were mounted on the exterior of the helicopter. The photomultiplier tube mounted to each $\mathrm{NaI}(\mathrm{Tl})$ crystal converted the scintillations of light in the crystal to electrical pulses. The electrical pulses from the eight crystals were normalized and combined in summing amplifiers to produce a single gamma ray energy spectrum useful for analyzing ow intensity sources. A single 4- $\times 4-\times 16$-in crystal provided a spectrum useful over highly active areas where the larger detectors would experience unacceptably large counting losses. Both spectra were simultaneously acquired and recorded, resulting in an increased dynamic range of sensitivity. Each pod also contained an upward-looking $3-\times 3$-in crystal that was used in conjunction with the eight large detectors to compute the effects of background radiation due to nonterrestrial sources.

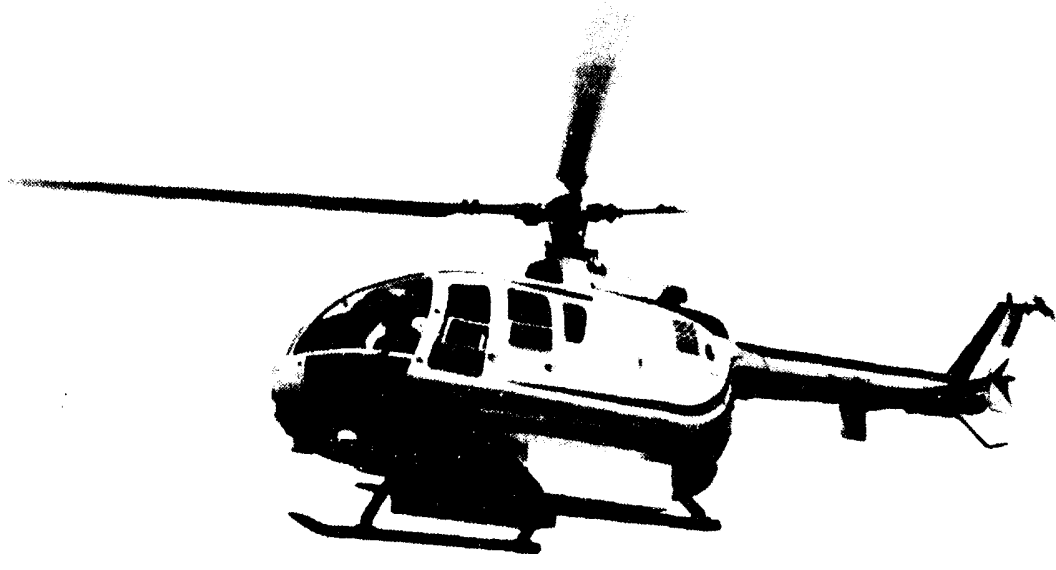

FIGURE B-1. MBB BO-105 HELICOPTER WITH DETECTOR PODS

The outputs from the summing amplifiers were analyzed in separate multichannel analyzers (MCAs) in the Radiation and Environmental Data Acquisition and Recorder (REDAR) system. Model IV. The REDAR system is a multi-microprocessor, portable data acquisition and realtime analysis system. It was designed to operate in the demanding environments associated with helicopters and fixed-wing aircraft. A block diagram of the REDAR system is shown in Figure B-2.

The inputs to the MCAs were adjusted so that the photopeaks due to calibration sources appeared in preselected channels. Each MCA collected a 1,024-channel gamma ray energy spectrum once every second. The collected spectrum was scaled to $4 \mathrm{keV}$ per channel. The 


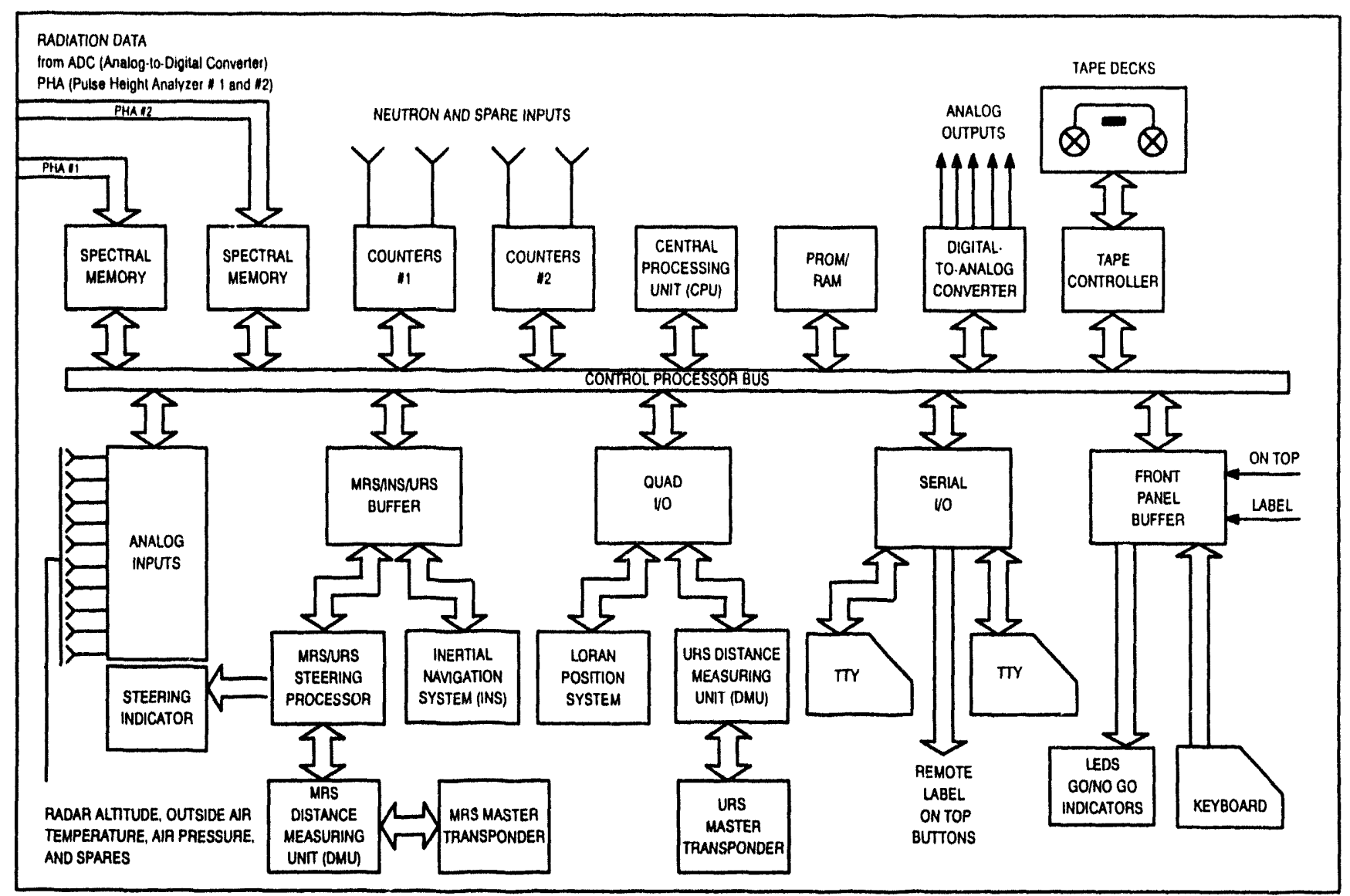

FIGURE B-2. BLOCK DIAGRAM OF THE REDAR SYSTEM

1,024-channel spectrum was compressed into 256 channels, as summarized in Table B-1, before storage on magnetic tape. The energy resolution of the NaI(Tl) crystals varies with energy such that the spectral data can be compressed without compromising photopeak identification and data analysis techniques. This spectral compression technique reduced the data storage requirement by a factor of four.

\begin{tabular}{|c|c|c|c|}
\hline \multicolumn{4}{|c|}{ Table B-1. REDAR IV Spectral Data Compressiona } \\
\hline $\begin{array}{c}\text { Energy Range } \\
\text { (keV) }\end{array}$ & $\begin{array}{c}\text { Input Channel } \\
\text { (linear at 4 } \\
\text { kaV/channel) }\end{array}$ & $\begin{array}{c}\text { Output Channel } \\
\text { (compressed) }\end{array}$ & $\begin{array}{c}\text { Output Channel } \\
\text { Energy Coefficiet } \\
\Delta E \text { (keV/channel) }\end{array}$ \\
\hline $0-302$ & $0-75$ & $0-75$ & 4 \\
$302-1,622$ & $76-405$ & $76-185$ & 12 \\
$1,622-4,070$ & $406-1,017$ & $186-253$ & 36 \\
$4,070-$ cutoff & $1,018-1,023$ & 254 & N/A \\
\hline
\end{tabular}

a To facilitate the data storage onto magnetic tape, the energy spectrum is compressed. 
Other information acquired and recorded by the REDAR system each second included aircraft positional data, system live-time information, and environmental conditions, i.e., absolute barometric pressure and outside air temperature.

The helicopter position was established by two systems: an ultrahigh frequency ranging system (URS) and a radar altimeter. The URS consisted of two remotely located transponders and an on-board interrogator that used the transit time of an ultrahigh frequency pulse radio to obtain the distance from the aircraft to each remote unit. The radar altimeter similarly measured the time delay for the return of a pulsed signal and converted this delay to aircraft altitude above ground level. In addition to being recorded on magnetic tape, position and altitude information were also processed in real time by the steering microprocessor. These data provided steering information to the pilot for flying predetermined flight lines at the desired altitude. 


\section{REFERENCES}

1. Boyns, P.K. An Aerial Radiological Survey of the Savannah River Plant (Aiken. South Carolina), Date of Survey: June 1974, Report No. EGG-1183-1665. EG\&G/EM, Las Vegas, Nevada, 1975.

2. Boyns, P.K., and D.B. Smith. An Aerial Radiological Survey of the Savannah River Plant and Surrounding Area, Aiken, South Carolina, Date of Survey: June 1979. Report No. EGG-1183-1816. EG\&G/EM, Las Vegas, Nevada, 1982.

3. Boyns, P.K. An Aerial Radiological Survey of the Beaufort-Jasper Water Treatment Plant and Canal, South Carolina, Date of Survey: March 1983, Report No. DOE/ONS-8311. EG\&G/EM, Las Vegas, Nevada, 1983.

4. Boyns, P.K. An Aerial Radiological Survey of the Cherokee Hill Water Treatment Plant. Georgia, Date of Survey: March 1983, Report No. DOE/ONS-8315. EG\&G/EM, Las Vegas, Nevada, 1983.

5. Boyns, P.K. An Aerial Radiological Survey of the Savannah River Floodplain, Date of Survey: July-October 1983, Report No. EGG-102.82-1049. EG\&G/EM, Las Vegas, Nevada, 1984.

6. Jobst, J.E. An Aerial Radiological Survey of the Savannah River Plant Drainage Basins, Date of Survey: August 1982, Report No. DOE/ONS-8312, Rev. 1. EG\&G/EM, Las Vegas, Nevada, 1987.

7. Jobst, J.E. An Aerial Radiological Survey of L Lake and Steel Creek, Savannah River Plant, Date of Survey: August 1985, Report No. DOE(ONS-SRL)-8611. EG\&G/EM, Las Vegas, Nevada, 1988.

8. Feimster, E.L. An Aerial Radiological Survey of the Beaufort-Jasper Water Treatment Plant, Beaufort, South Carolina, Date of Survey: July-August 1986, Report No. DOE(ONS-SRL)-8704. EG\&G/EM, Las Vegas, Nevada, 1987.

9. Feimster, E.L. An Aerial Radiological Survey of the Cherokee Hill Water Treatment Plant, Port Wentworth, Georgia, Date of Survey: August 1986, Report No. DOE(ONS-SRL)-8706. EG\&G/EM, Las Vegas, Nevada, 1987.

10. Feimster, E.L. An Aerial Radiological Survey of L Lake and Stcel Creek, Savannah River Plant, Date of Survey: July 1986, Report No. EGG-10617-1146. EG\&G/EM, Las Vegas, Nevada, 1992.

11. Feimster, E.L. An Aerial Radiological Survey of Par Pond and Associated Drainage Pathways, Savannah River Site, August-September 1991, Report No. EGG-10617-1227. EG\&G/EM, Las Vegas, Nevada, 1992. 
12. Feimster, E.L. Aerial Radiological Surveys of Steed Pond, Savannah River Site, 1984-1989, Report No. EGG 10617-1192. EG\&G/EM, Las Vegas, Nevada, 1993.

13. Feimster, E.L. A Comparison of Four Aerial Radiological Surveys of Par Pond and the Surrounding Area, Savannah River Site, 1989-1992, Report No. EGG-1 1265-1009. EG\&G/EM, Las Vegas, Nevada, 1993. 
DOE/DP
L. E. Gordon-Hagerty
O.W. Taylor

(1)

(1)

(25)

DOE/NV

M.R. Dockter
C.A. Santilli

(1)

DOE/SR
J. D. Arnett
E. C. Goodson
A. B. Gould, Jr.
S. R. Wright

(2)

(5)

(2)

(2)

SRS/WSRC
A. L. Boni
T. S. DeHart
J. B. Gladden

(1)

(5)

(1)
SRS/WSRC (continued)

D.W. Hayes

H. E. Mackey

D. B. Moore-Shedrow

(1)

\section{EG\&G/EM}

$\begin{array}{lll}\text { Z. G. Burson } & \text { LVAO } & (1) \\ \text { H.W. Clark } & \text { LVAO } & (1) \\ \text { J. F. Doyle } & \text { LVAO } & (1) \\ \text { E. L. Feimster } & \text { LVAO } & (1) \\ \text { P.P. Guss } & \text { WAMO } & (1) \\ \text { T. J. Hendricks } & \text { LVAO } & (1) \\ \text { J. E. Jobst } & \text { LVAO } & (1) \\ \text { R. A. Meibaum } & \text { LVAO } & (1) \\ \text { C. K. Mitchell } & \text { LVAO } & (1) \\ \text { G.R. Shipman } & \text { WAMO } & (1) \\ \text { L.R. Tinney } & \text { LVAO } & (1) \\ \text { W. J. Tipton } & \text { LVAO } & (1) \\ \text { P. H. Zavattaro } & \text { LVAO } & (1) \\ & & \end{array}$

\section{LIBRARIES}

RSL

SBO

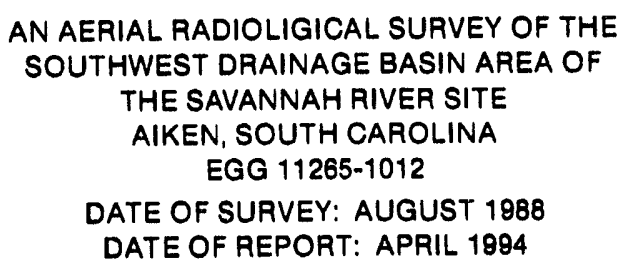



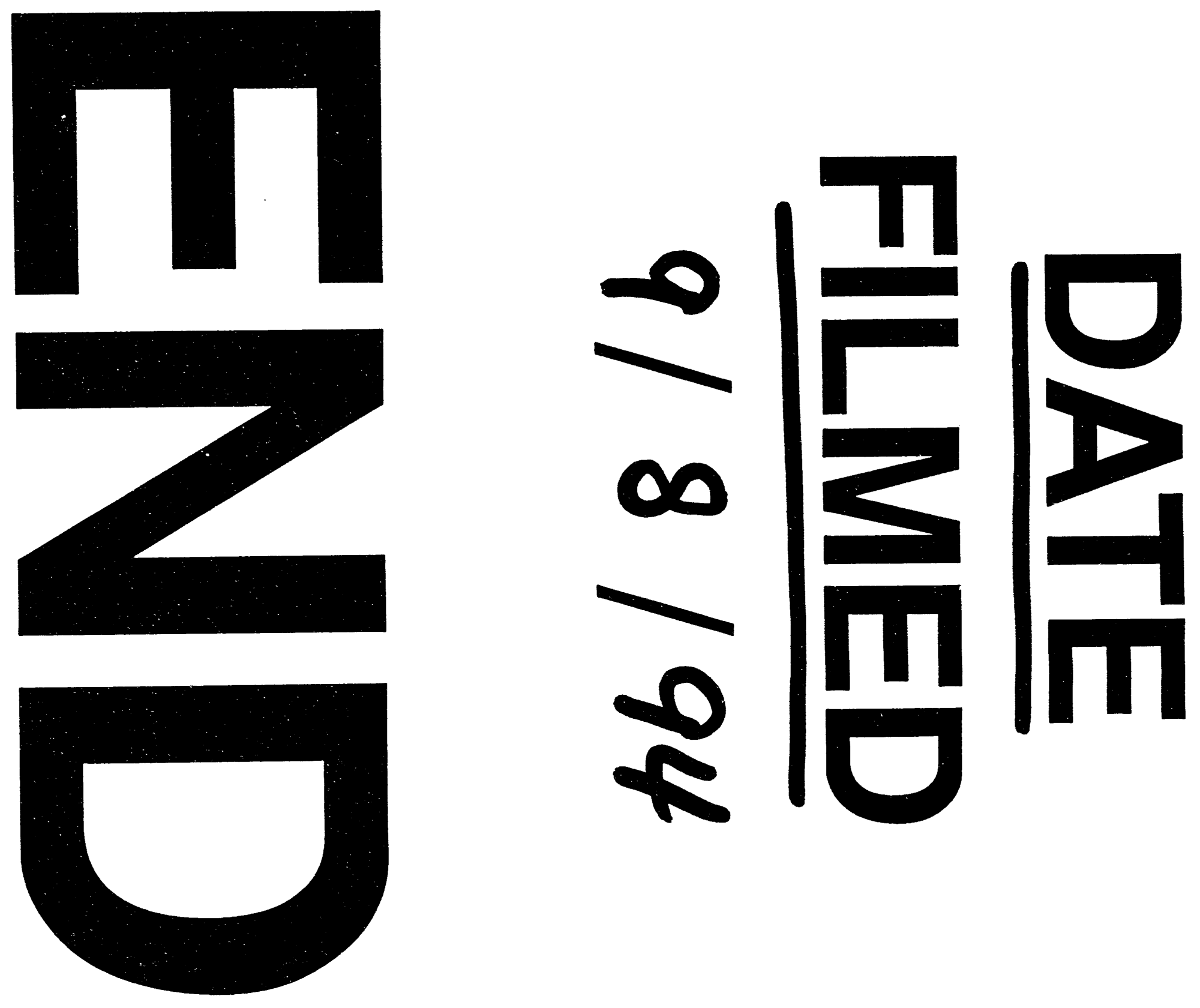
